\title{
Summertime free-tropospheric ozone pool over the eastern Mediterranean/Middle East
}

\author{
P. Zanis ${ }^{1}$, P. Hadjinicolaou ${ }^{2}$, A. Pozzer ${ }^{3}$, E. Tyrlis ${ }^{2}$, S. Dafka ${ }^{1,4}$, N. Mihalopoulos ${ }^{2,5}$, and J. Lelieveld ${ }^{2,3}$ \\ ${ }^{1}$ Department of Meteorology and Climatology, School of Geology, Aristotle University of Thessaloniki, University Campus, \\ Thessaloniki, Greece \\ ${ }^{2}$ Energy, Environment and Water Research Center, The Cyprus Institute, Nicosia, Cyprus \\ ${ }^{3}$ Max Planck Institute for Chemistry, Mainz, Germany \\ ${ }^{4}$ Climatology, Climate Dynamics and Climate Change, Department of Geography, Justus-Liebig University of Giessen, \\ Giessen, Germany \\ ${ }^{5}$ Environmental Chemical Processes Laboratory, Department of Chemistry, University of Crete, Heraklion, Greece
}

Correspondence to: P. Zanis (zanis@geo.auth.gr)

Received: 23 May 2013 - Published in Atmos. Chem. Phys. Discuss.: 23 August 2013

Revised: 15 November 2013 - Accepted: 27 November 2013 - Published: 3 January 2014

\begin{abstract}
Observations show that the Mediterranean troposphere is characterized by a marked enhancement in summertime ozone, with a maximum over the eastern Mediterranean. This has been linked to enhanced photochemical ozone production and subsidence under cloud-free anticyclonic conditions. The eastern Mediterranean is among the regions with the highest levels of background tropospheric ozone worldwide. A $12 \mathrm{yr}$ climatological analysis (1998-2009) of free-tropospheric ozone was carried out over the region based on the ECMWF (European Centre for Medium-Range Weather Forecasts) ERA-Interim reanalysis data and simulations with the EMAC (ECHAM5-MESSy) atmospheric chemistry-climate model. EMAC is nudged towards the ECMWF analysis data and includes a stratospheric ozone tracer. A characteristic summertime pool with high ozone concentrations is found in the middle troposphere over the eastern Mediterranean-Middle East (EMME) in the ERAInterim ozone data, Tropospheric Emission Spectrometer (TES) satellite ozone data and simulations with EMAC. The enhanced ozone over the EMME during summer is a robust feature, extending down to lower free-tropospheric levels. The investigation of ozone in relation to potential vorticity and water vapour and the stratospheric ozone tracer indicates that the dominant mechanism causing the free-tropospheric ozone pool is the downward transport from the upper troposphere and lower stratosphere, in association with the enhanced subsidence and the limited horizontal divergence ob-
\end{abstract}

served over the region. The implications of these high freetropospheric ozone levels on the seasonal cycle of nearsurface ozone over the Mediterranean are discussed.

\section{Introduction}

Ozone is central in the control of the oxidizing capacity of the troposphere (Chameides and Walker, 1973; Crutzen, 1988; Penkett, 1988). Furthermore, ozone is a greenhouse gas and its increase causes a radiative forcing leading to warming at the Earth's surface (IPCC, 2007). Ozone in the free troposphere has a longer lifetime compared to the boundary layer, which enables transport on regional to hemispheric scales, and it has a proportionally greater influence on climate than ozone near the surface (Lacis et al., 1990). The main sources of tropospheric ozone are photochemically production through oxidation of volatile organic compounds (VOCs) and $\mathrm{CO}$ in the presence of $\mathrm{NO}_{\mathrm{x}}$ and stratosphereto-troposphere transport (STT) (e.g. Lelieveld and Dentener, 2000). Nowadays, there is broad agreement that photochemistry is the major contributor to the observed background ozone levels in the troposphere (Crutzen et al., 1999; Lelieveld and Dentener, 2000). Nevertheless, stratosphereto-troposphere transport (STT) can be important in the middle and upper troposphere in regions where meteorological conditions favour downward transport, and in cases of deep 
stratospheric intrusions reaching into the lower troposphere (Roelofs and Lelieveld, 1997; Sprenger and Wernli, 2003; Akritidis et al., 2010).

During boreal summer, the eastern Mediterranean (EM) is considered to be one of the air pollution hotspots featuring comparatively higher levels of lower tropospheric ozone owing to the cloud-free conditions, high solar radiation intensity and because it is at the crossroads of polluted air masses from Europe, Africa and Asia (Zerefos et al., 2002; Lelieveld et al., 2002; Kanakidou et al., 2011). Furthermore, the EM is also favourable to deep STT events because it lies southwards of the typical position of the polar front jet at the ending point of a pathway characteristic of stratospheric intrusions (Galani et al., 2003; Sprenger and Wernli, 2003).

These high ozone levels can strongly impact regional air quality and radiative forcing. The EU air quality standard for human health protection is often exceeded during summer, as shown by measurements at rural and baseline stations located upwind of urban areas (Kourtidis et al., 1996; Kalabokas and Bartzis, 1998; Kalabokas et al., 2000; Kouvarakis et al., 2000; Kalabokas and Repapis, 2004; Gerasopoulos et al., 2005) as well as measurements during campaigns over the Aegean (Kourtidis et al., 2002; Kouvarakis et al., 2002). Recently, Richards et al. (2013) showed that both the Tropospheric Emission Spectrometer (TES) and the Global Ozone Monitoring Experiment-2 (GOME-2) satellite instruments were able to detect enhanced levels of ozone in the lower troposphere over the Mediterranean region during the summer. Results from chemistry transport models (CTMs) indicate that the largest portion of this high ozone over the EM is beyond local emission controls (Zerefos et al., 2002) and that ozone in the lower troposphere originates mainly from the European continent (Roelofs et al., 2003). Biogenic emissions during summer may also impact the ozone levels in the lower troposphere of the Mediterranean Basin (Liakakou et al., 2007; Richards et al., 2013) since they are very sensitive to temperature changes (Im et al., 2011).

An important meteorological factor associated with these elevated boundary layer and surface ozone levels is the anticyclonic conditions over the central Mediterranean and the Balkans leading not only to enhanced photochemical ozone production but also tropospheric subsidence (Kalabokas et al., 2007, 2008). Another important factor is the long-range transport of air masses from Europe, which are rich in ozone and ozone precursors, towards the sunlit EM, especially over the Aegean Sea, in addition to emissions from local sources (Zerefos et al., 2002; Kouvarakis et al., 2002). The Etesians, which dominate the circulation during the summer and early autumn over the Aegean Sea and EM, with persistent northerly winds in the lower troposphere, set up the typical transport regime (Repapis, 1977; Kallos et al., 1998; Poupkou et al., 2011; Anagnostopoulou et al., 2013). Recently, Kalabokas et al. (2013) concluded that the highest ozone concentrations in the lower troposphere over the EM, notably in the boundary layer, are associated with large-scale subsi- dence from the upper troposphere, which is a characteristic feature of the EM summer circulation inhibiting cloud formation and convection. The dynamics of the Etesians are tightly interwoven with the large-scale subsidence observed over the EM and both are interconnected manifestations of the remote south Asian monsoon forcing (Rodwell and Hoskins, 1996, 2001; Ziv et al., 2004; Tyrlis et al., 2013a). Essentially the monsoon regulates the summer EM circulation, while the shorter term variability is controlled by the mid-latitude dynamics and features alternating phases of enhanced northerly flow (Etesian outbreaks) interrupted by quiet spells (Tyrlis and Lelieveld, 2013).

There are also a number of studies reporting high ozone in the middle and upper troposphere which extend to larger geographical areas over the eastern Mediterranean-Middle East (EMME). In earlier observational studies, vertical profiles from the MOZAIC programme on commercial aircraft have already indicated high summer mixing ratios over the area (Marenco et al., 1998; Stohl et al., 2001). Modelling studies showed high ozone values at $500 \mathrm{hPa}$ over the Middle East in July (Jonson et al., 2001; Li et al., 2001). Li et al. (2001) simulated with a CTM a summertime ozone maximum over the Middle East, with mean mixing ratios in the middle and upper troposphere in excess of $80 \mathrm{ppbv}$ being consistent with the few observations from commercial aircraft in the region. Roelofs et al. (2003) reported a layer of 4-6 km thickness over the region with up to $120 \mathrm{ppbv}$ of ozone based on both observations and model simulations.

An important dynamical mechanism controlling the chemical composition of the middle and upper troposphere over the area is an inherent feature of the Indian summer monsoon, the Tropical Easterly Jet (TEJ) stream, a belt of strong easterly winds which transports air from Asia over northern Africa between 200 and $100 \mathrm{hPa}$ and, aided by the uppertropospheric anticyclone over the Arabian Peninsula, toward the EM (Scheeren et al., 2003). Li et al. (2001) concluded that the anticyclonic circulation in the middle and upper troposphere over the Middle East funnels northern mid-latitude pollution, transported in the westerly subtropical jet, as well as lightning $\mathrm{NO}_{\mathrm{x}}$ from the Indian monsoon and pollution from eastern Asia transported in the TEJ. Recently, Richards et al. (2013) performed CTM simulations and found that in the mid- and upper troposphere almost all ozone originates from long-range transport, with the Asian monsoon outflow having the greatest impact.

On the other hand, there are contradicting results regarding the impact of STT on these high ozone levels in the middle and upper troposphere. For example, Li et al. (2001) reported that transport from the stratosphere does not contribute significantly to these high ozone levels, while Roelofs et al. (2003) found substantial contributions by transport from the stratosphere. Also, a study of stratosphere-troposphere exchange (STE) over the EM indicated that cross-tropopause transport can be intense, which is related to the distinct summertime meteorological conditions over south Asia and the 
Arabian Peninsula (Traub and Lelieveld, 2003). Recently, Lelieveld et al. (2009) linked the summertime high middletroposphere ozone levels over the Middle East with severe near-surface ozone air pollution in the Persian Gulf region, highlighting also the important contribution of stratospheric ozone.

The aim of this work is to investigate the role and the contribution of the controlling transport mechanisms accounting for the characteristic summertime ozone pool in the middle troposphere over the EMME, which extends down to lower free-tropospheric levels and the implications for near-surface ozone at the Mediterranean Basin. Section 2 describes the ERA-Interim, TES, EMAC and near-surface ozone data used in this study. Section 3 presents the results related to the characteristic summertime ozone pool in the middle troposphere over the EMME, the links with atmospheric circulation and the implications for the near-surface ozone, while Sect. 4 discusses our results and summarizes the main conclusions.

\section{Data and EMAC model description}

\subsection{ERA-Interim data}

ERA-Interim is the latest global atmospheric reanalysis produced by the European Centre for Medium-Range Weather Forecasts (ECMWF), covering the period from 1 January 1979 onwards and continuously updated to the present (Dee et al., 2011). The ERA-Interim atmospheric model and reanalysis system is configured with the following spatial resolution: 60 vertical levels up to $0.1 \mathrm{hPa}, \mathrm{T} 255$ sphericalharmonic representation for the basic dynamical fields, and a reduced Gaussian grid with approximately uniform $79 \mathrm{~km}$ spacing for surface and other grid-point fields (Berrisford et al., 2011). Information about the current status of ERAInterim production, availability of data online and nearreal-time updates of various climate indicators derived from ERA-Interim data can be found at http://www.ecmwf.int/ research/era.

Focusing on the ozone product, Dethof and Hólm (2004) have described in detail the main characteristics the ECMWF ozone system of the ERA-40 reanalysis project. As pointed out by Dethof and Hólm (2004), the ozone first guess used at ECMWF is derived from an updated version of the Cariolle and Déqué (1986) scheme. In this scheme, the ozone continuity equation is expressed as a linear relaxation towards a photochemical equilibrium for the local value of the ozone mixing ratio, the temperature and the overhead ozone column. An additional ozone destruction term is used to parameterize the heterogeneous chemistry as a function of the equivalent chlorine content for the actual year (relevant for the stratosphere). Most of that discussion still applies to ERA-Interim, although a number of changes and improvements were implemented in the latest reanalysis project. A description of the implemented scheme improvements can be found in Cariolle and Teyssédre (2007). It should be also noted that the ozone data assimilated in ERA-Interim use a larger data set than was used for ERA-40, for example the Global Ozone Monitoring Experiment (GOME) ozone profiles (Dragani, 2011). Dragani (2011) carried out a quality assessment of the ERA-Interim ozone product, essentially for the stratospheric levels and the mean total column ozone (TCO), showing generally consistent results when compared with ozone retrievals from a number of satellite instruments. The ERA-Interim data used in the current analysis include monthly mean values of ozone, potential vorticity, specific humidity and the three components of the wind ( $u, v$ and $w)$ at 27 pressure levels from 1000 up to $100 \mathrm{hPa}$ for the period 1998-2009.

\subsection{TES and EMEP ozone data}

The Tropospheric Emission Spectrometer (TES) on the Earth Observing System (EOS) Aura mission is a high-resolution infrared imaging Fourier transform spectrometer covering the spectral range $650-3050 \mathrm{~cm}(3.3-15.4 \mathrm{~m})$ at a spectral resolution of $0.1 \mathrm{~cm}^{-1}$ for nadir viewing or $0.025 \mathrm{~cm}^{-1}$ for limb viewing (Beer et al., 2001; Beer, 2006). At the level 2 (L2) processing step, TES-calibrated spectral radiances derived from the observed interferograms at level 1B (L1B) are used to retrieve vertical profiles $0-32 \mathrm{~km}$ of atmospheric temperature and chemical species such as carbon monoxide, ozone, methane and water vapour on a global scale every other day. These L2 data at the observation geolocations and times are used as the inputs to produce the TES level 3 (L3) data that fill with horizontal interpolation the spatial gaps in global scale of the L2 orbital data (http://tes.jpl.nasa.gov/uploadedfiles/Level3 UserGuide_v1.0.pdf). The TES L3 ozone data provides information for mapping the global distribution of tropospheric ozone with special focus on understanding the factors that control ozone concentrations (Osterman et al., 2008; Voulgarakis et al., 2011). The TES data used in the current analysis include daily L3 ozone values for the period 2005-2009 with grid spacing $4^{\circ} \times 2^{\circ}$ in longitude and latitude.

Furthermore, in our analysis we considered near-surface ozone data from four baseline maritime ozone stations in the Mediterranean Basin (see Fig. 1) from the EMEP (European Monitoring and Evaluation Programme) network at (a) Cabo de Creus, Spain (ES10, 42.32 ${ }^{\circ}$ N, 3.32 ${ }^{\circ}$ E); (b) Giordan Lighthouse, Gozo, Malta (MT01, 36.07 $\mathrm{N}, 14.22^{\circ} \mathrm{E}$ ); (c) Finokalia-Crete, Greece (GR02, $\left.35.32^{\circ} \mathrm{N}, 25.67^{\circ} \mathrm{E}\right)$; and (d) Ag. Marina, Cyprus $\left(\mathrm{CY} 02,35.07^{\circ} \mathrm{N}, 33.12^{\circ} \mathrm{E}\right)$. The stations MT01, GR02 and CY02 started operation in 1997. while ES10 in 1999.

\subsection{EMAC model description and setup}

The data used in this study are from a simulation with the ECHAM5-MESSy for Atmospheric Chemistry (EMAC) 


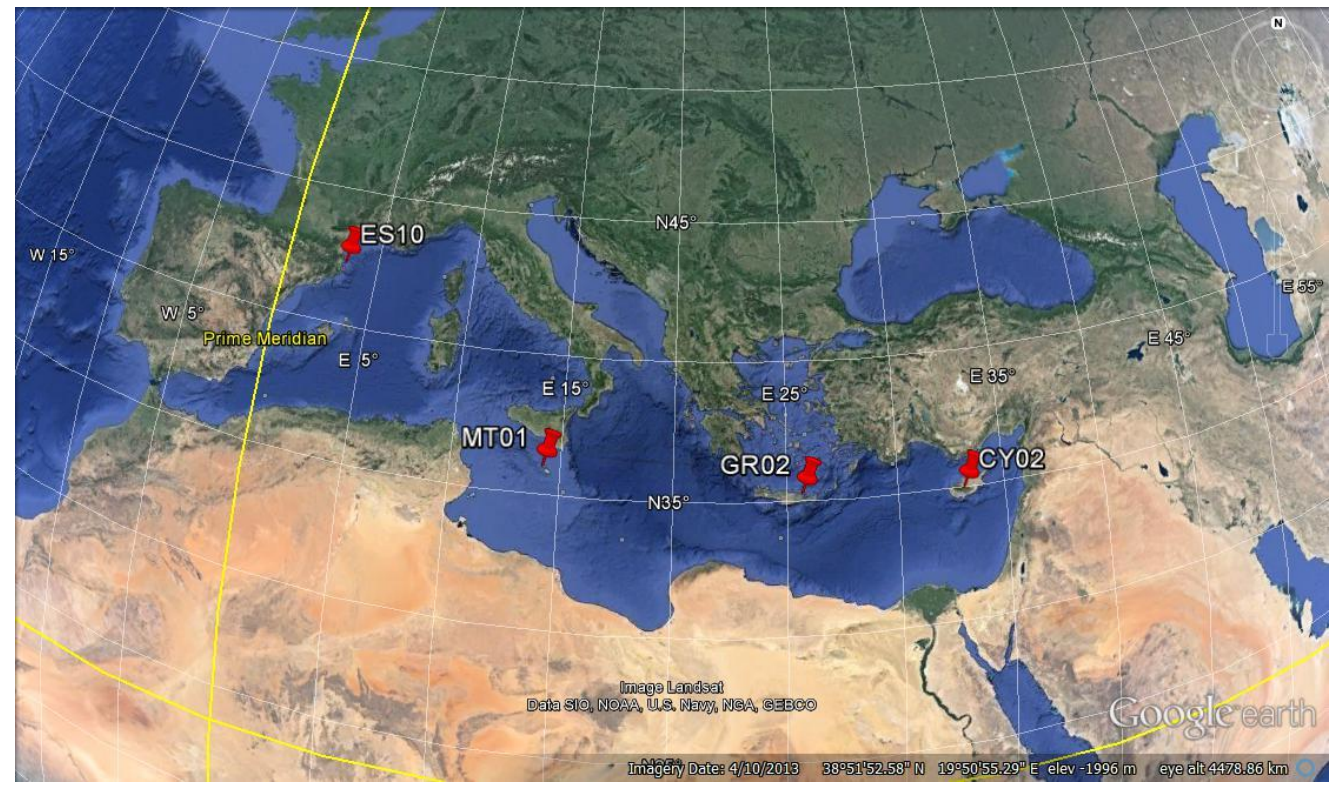

Fig. 1. Map of the Mediterranean Basin with the locations of the four EMEP stations marked: Cabo de Creus, Spain (ES10); Gozo, Malta (MT01); Finokalia, Greece (GR02); and Ag. Marina, Cyprus (CY02). Keep in mind that the positions of the cross sections of Figs. 5 and 7 are indicated in the map by the $35^{\circ} \mathrm{N}$ meridian and the $25^{\circ} \mathrm{E}$ parallel crossing the island of Crete, Greece.

model, comprising the fifth-generation European CentreHamburg general circulation model (GCM), ECHAM5 (Roeckner et al., 2006) coupled to the Modular Earth Submodel System, MESSy (Jöckel et al., 2005). The EMAC modelling system represents emissions, multiphase reactions, deposition and transport of chemical species, as well as radiation, cloud and dynamical processes from the surface up to the mesosphere. The modelled ozone data used in this study are taken from the EMAC version 2 run (Jöckel et al., 2010), based on an extensive evaluated version of the model (Jöckel et al., 2006; Pozzer et al., 2007). The model has a horizontal resolution of around $2.8^{\circ}$ in longitude and latitude (T42 in spectral truncation). In the vertical direction the model has 90 layers from the ground to $0.01 \mathrm{hPa}, 19$ of which lie between the middle troposphere and the lower stratosphere (approximately between 500 and $100 \mathrm{hPa}$ ) and adequately resolving the region around the tropopause, allowing for realistic stratosphere-troposphere interactions (Lelieveld et al., 2007). The model run was originally to cover the period 1998-2008, but the simulation was extended by an additional year, i.e. until the end of 2009. The simulation was nudged towards the actual tropospheric meteorology (excluding the boundary layer and up to $100 \mathrm{hPa}$ ), with temperature, surface pressure, divergence and vorticity data from the operational forecast analyses of the ECMWF.

The chemical mechanism includes 110 species and a total of 286 gas-phase, heterogeneous and liquid-phase reactions (Sander et al., 2011; Tost et al., 2006), applied from the surface to the top of the model domain, therefore enabling the consistent simulation of ozone transport from the stratosphere to the troposphere. A tracer for stratospheric ozone (denoted by $\mathrm{O} 3 \mathrm{~s}$ ) is also employed in order to facilitate the investigation of stratospheric contribution to tropospheric ozone. The O3s tracer adopts the model ozone values in the stratosphere and follows the transport and destruction processes of ozone in the troposphere. When (or if) O3s enters back into the stratosphere it is re-initialized at stratospheric values (Roelofs and Lelieveld, 1997).

\section{Results}

\subsection{Middle-troposphere summertime ozone maximum}

The monthly average ozone fields at $500 \mathrm{hPa}$ based on ERAInterim ozone over the period 1998-2009 (Fig. 2) show a latitudinal distribution of ozone with highest values towards the south for all months except from June to September. Specifically, in June an area with maximum ozone concentrations develops over the EMME, which becomes more pronounced in July and August. This characteristic pool of high ozone values in the middle troposphere over the EMME is not solely a feature seen in the ERA-Interim data but is also in observed ozone data like the TES profiles. The daily TES ozone data were used to calculate the ozone anomalies in the middle troposphere $(464 \mathrm{hPa})$ for July-August over the period 2005-2009 (Fig. 3b). Figure 3a shows the ozone anomalies for July-August at $450 \mathrm{hPa}$ obtained from the ERAInterim data for the same period (2005-2009) and using the same days in accordance with TES data. Comparison 
a) January ERA-interim 03 (ppby) at $500 \mathrm{hPa}$

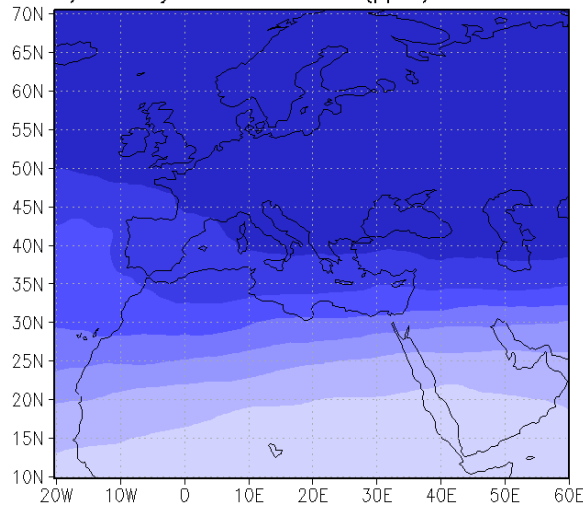

c) March ERA-interim 03 (ppbv) at $500 \mathrm{hPo}$

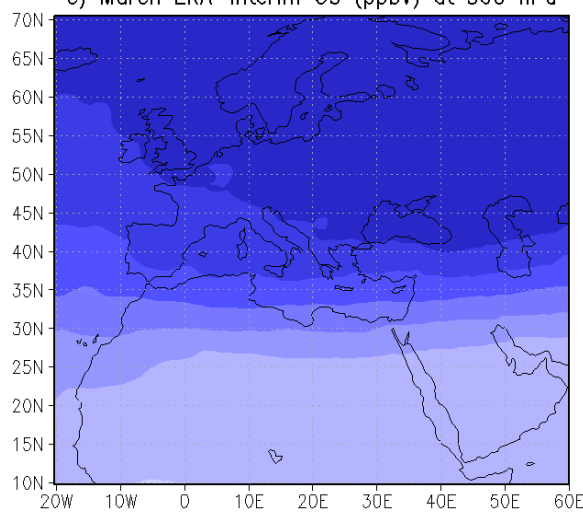

e) May ERA-interim 03 (ppbv) at $500 \mathrm{hPa}$

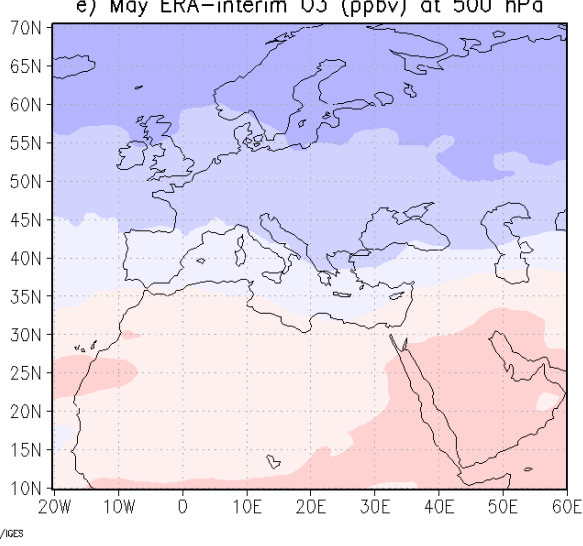

b) February ERA-interim 03 (ppbv) at $500 \mathrm{hPa}$

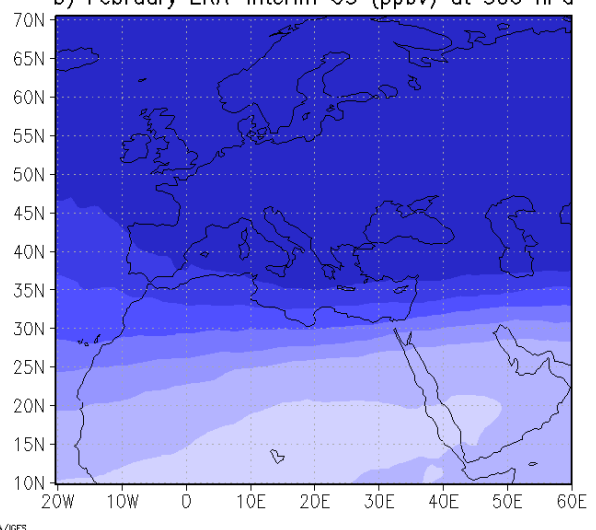

d) April ERA-interim 03 (ppbv) at $500 \mathrm{hPa}$
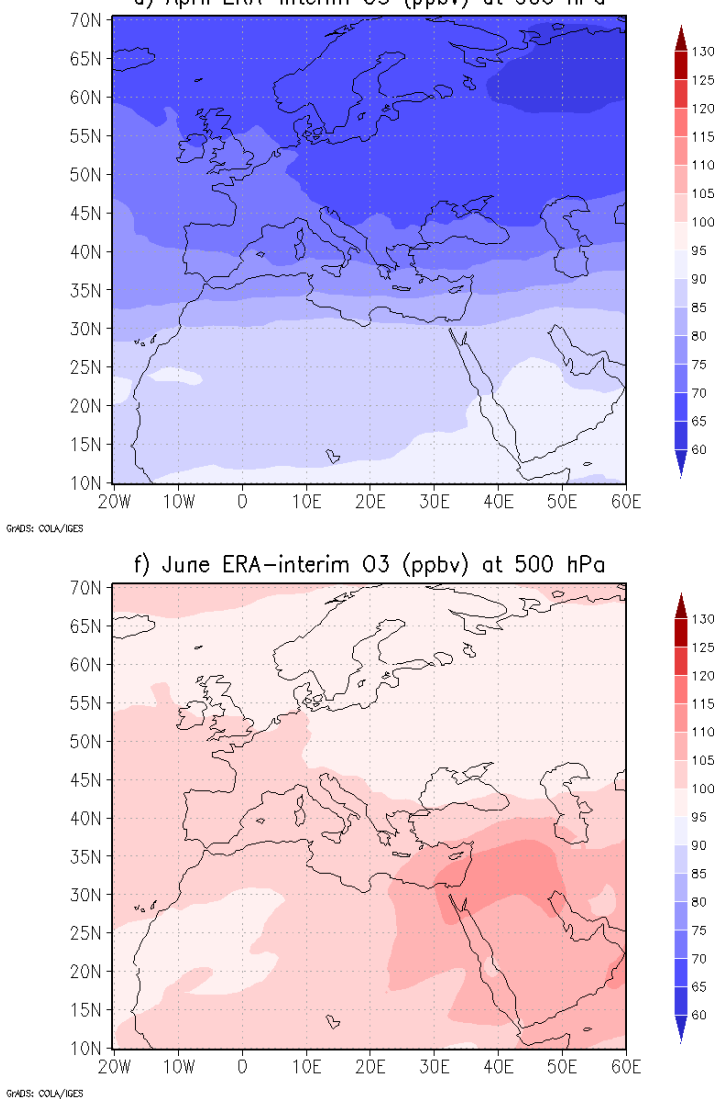

Fig. 2. Monthly average ozone fields at $500 \mathrm{hPa}$ based on ERA-Interim ozone (ppbv) over the period 1998-2009 for (a) January, (b) February, (c) March, (d) April, (e) May, (f) June, (g) July, (h) August, (i) September, (j) October, (k) November, (l) December.

of both TES and ERA-Interim ozone fields clearly corroborates the pool with higher ozone values in the middle troposphere over EMME. A geographical shift of the maximum ozone anomalies between ERA-Interim and TES ozone data can be attributed to the coarser grid resolution of L3 TES data $\left(4^{\circ} \times 2^{\circ}\right)$ compared to ERA-Interim $\left(0.75^{\circ} \times 0.75^{\circ}\right)$ and limitations of the simplified ozone chemistry scheme in the ECMWF model, which misses part of the photochemical ozone buildup over the EM.

\subsection{Ozone links with circulation}

The ERA-Interim July-August average fields of ozone at $700 \mathrm{hPa}$ (Fig. 4a) indicate that the pool with high ozone values is also present in the lower troposphere. Hence it appears that the enhanced ozone over the EMME is a robust feature, extending down to the lower free troposphere. Inspection of the July-August ozone fields at $250 \mathrm{hPa}$ (Fig. 4c) shows a structure of high ozone penetrating southwards 
g) July ERA-interim 03 (ppbv) at $500 \mathrm{hPo}$

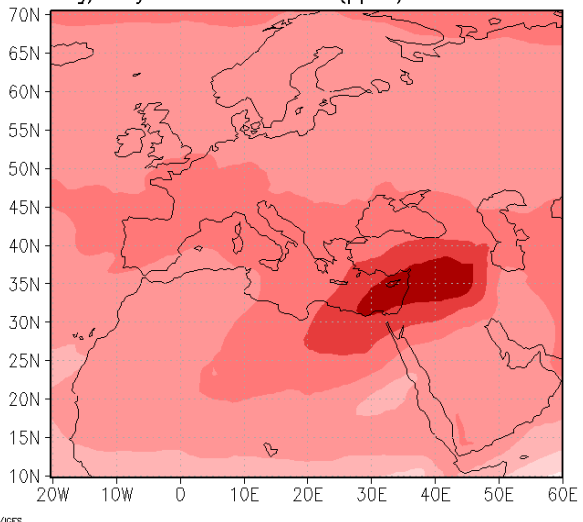
GrADS: COLAIGES

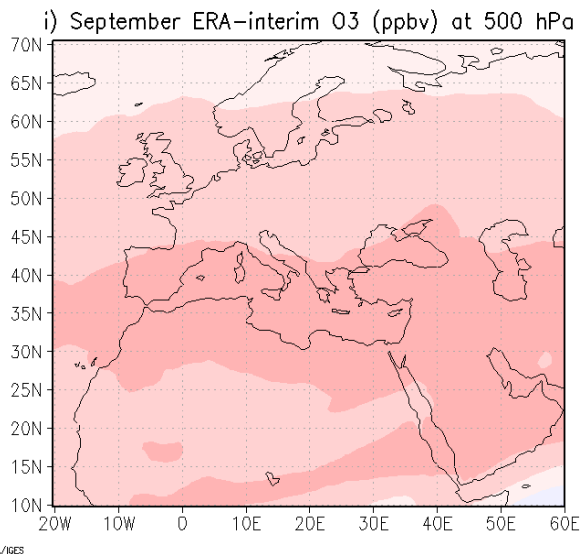
GrADS: CLLAIGES

k) November ERA-interim 03 (ppbv) at $500 \mathrm{hPo}$

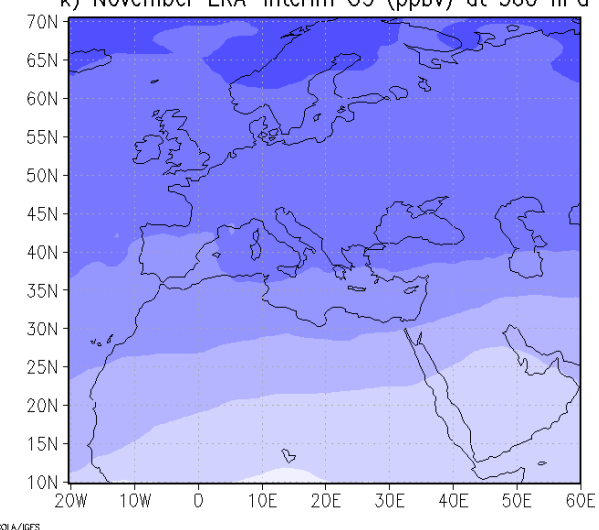

h) August ERA-interim $03(\mathrm{ppbv})$ at $500 \mathrm{hPa}$

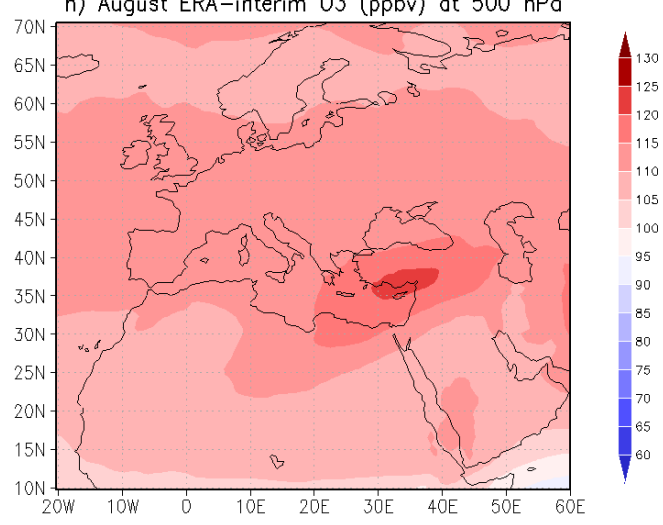

GAOAS: OOW/GE

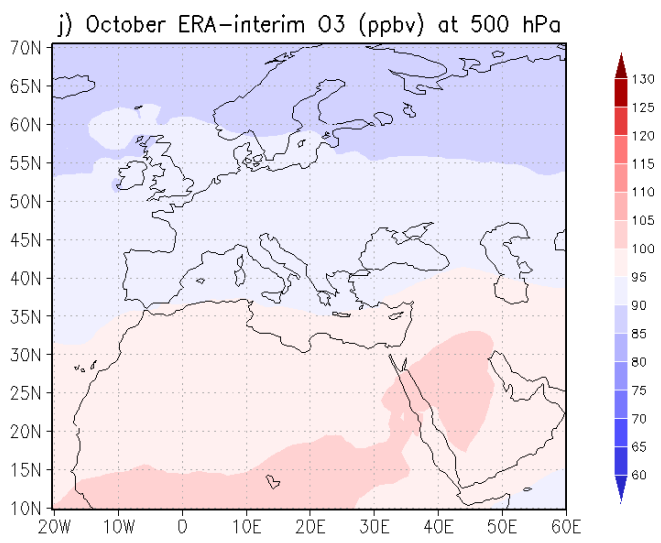

GRASS: COLWGES

1) December ERA-interim 03 (ppbv) at $500 \mathrm{hPo}$

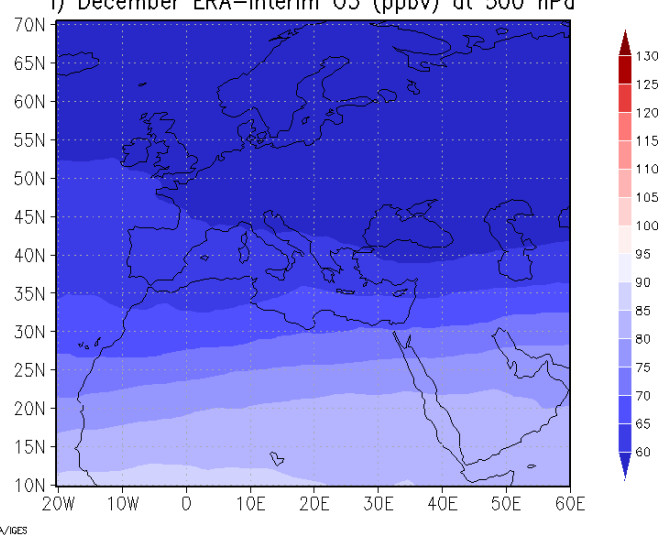

Fig. 2. Continued.

over south-eastern Europe and the EM, implying upper troposphere-lower troposphere links through meteorological processes.

It is well known that tropopause folding events at midlatitudes are characterized by tongues of anomalously high potential vorticity (PV), high ozone and low specific humidity (SH) (Holton et al., 1995). Both PV and SH are typical tracers to accompany ozone analysis in case studies of transport from the lower stratosphere or upper troposphere into the middle and lower troposphere. It can be inferred from the comparison of Fig. $4 \mathrm{a}$ and $\mathrm{b}$ with Fig. $4 \mathrm{~d}, \mathrm{e}, \mathrm{g}$ and $\mathrm{h}$ that the high ozone values in middle and lower troposphere are accompanied by lower SH and structures of higher PV streamers extending southwards. The 500 and $700 \mathrm{hPa}$ PV values are below typical stratospheric values (> 2 pvu) due to averaging in monthly timescales and mixing processes. It is interesting to note in Fig. 4e and k (at $500 \mathrm{hPa}$ ) as well as in Fig. $4 \mathrm{f}$ and 1 (at $250 \mathrm{hPa}$ ) that the region with the highest subsidence 

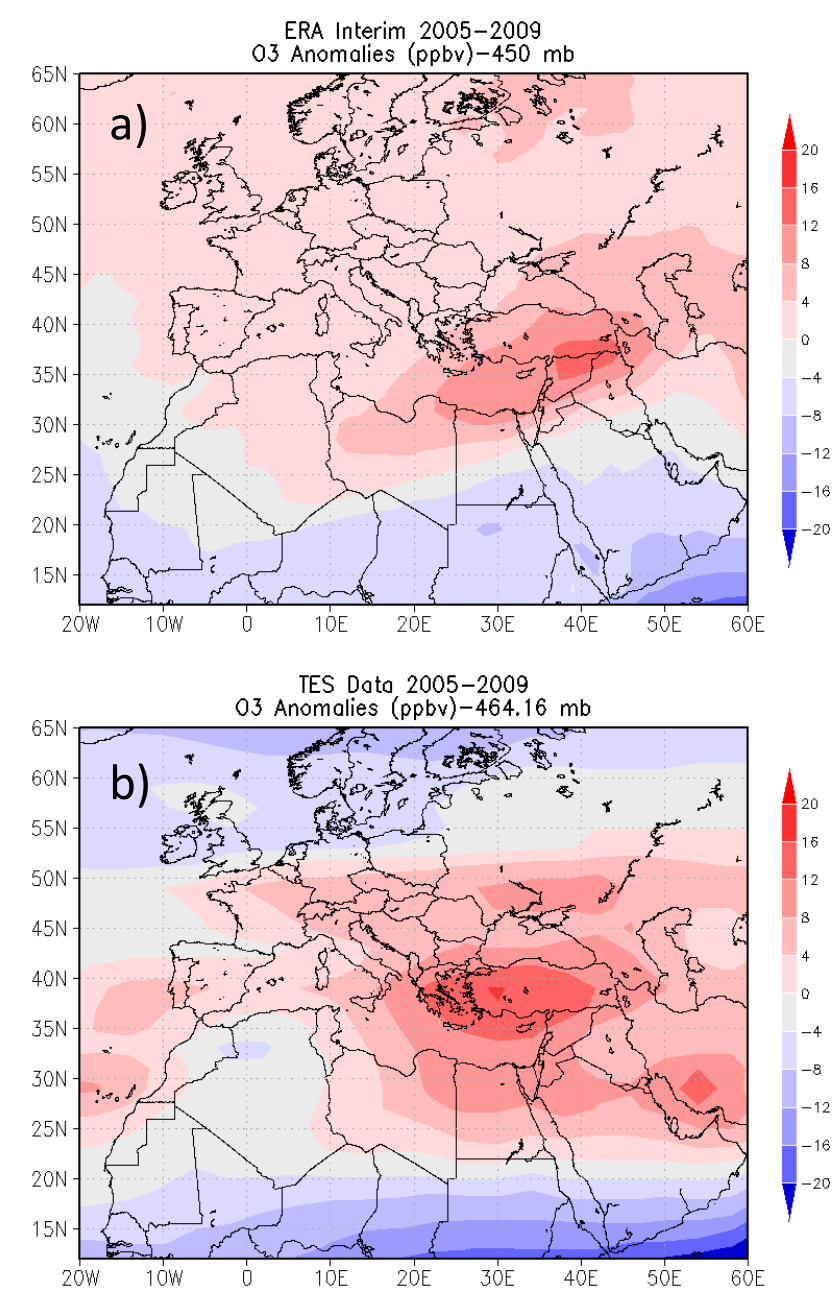

Fig. 3. July-August average ozone anomaly fields (ppbv) over the period 2005-2009 based on (a) ERA-Interim ozone at $450 \mathrm{hPa}$, and on (b) TES observed ozone at $464 \mathrm{mb}$. Ozone anomalies were calculated as the differences between the July-August mean at each grid point and the July-August mean of the whole area of the domain.

is located on the western flank of the higher PV streamers extending southwards, as would be expected from a dynamical perspective with anomalous subsidence upstream a positive PV anomaly (Hoskins et al., 1985). Taking into account the study of Sprenger et al. (2007), which identified a STT maximum on the western flank of the stratospheric PV streamers, a coincidence of the region with the strongest subsidence and that of maximum STT is implied. It is also interesting to note that there is a shift towards the south-east (at 500 and $700 \mathrm{hPa}$ ) or towards the east (at $250 \mathrm{hPa}$ ) of the maximum of ozone and the minimum of specific humidity structures with respect to the maximum of subsidence. This horizontal shift can be attributed to the persistent north-westerly flow at 500 and $700 \mathrm{hPa}$ (Fig. $4 \mathrm{j}$ and k) or the westerly flow at $250 \mathrm{hPa}$ (Fig. 4l). Hence the maxima of ozone or the minima of specific humidity lie a bit downstream to the areas

of strongest subsidence. Most importantly, the location of the ozone maximum is observed further downstream towards the south-eastern Mediterranean at lower tropospheric levels. For example, the maximum of ozone and the minimum of specific humidity at $700 \mathrm{hPa}$ are located over the Sinai Peninsula, whereas in the mid-troposphere the ozone pool and drier air masses are encountered further to the north-west. This is related to the nearly isentropic sloping and downgliding of the air masses towards the Levantine region that also results in the formation of rare deeper folds over the Levantine region (Tyrlis et al., 2013b).

It is interesting that the horizontal divergence in the middle and the lower free troposphere at the area of subsidence is minor (Fig. $4 \mathrm{j}$ and $\mathrm{k}$ ). In fact there is limited divergence for the largest part of the tropospheric column between 350 and $800 \mathrm{hPa}$, with the air masses converging at the top around 200-300 hPa (e.g. see Fig. 4l) and diverging in the boundary layer (below $850 \mathrm{hPa}$ ).

The consistency among the fields of ozone, $\mathrm{PV}$ and $\mathrm{SH}$ from the upper to lower troposphere imply the dominating role of transport for the higher ozone values over the EMME. The higher ozone, higher PV and lower SH over the EMME are related through the strong subsidence over the region in combination with the horizontal advection, as illustrated in Fig. $4 \mathrm{i}, \mathrm{k}$ and 1.

The penetration of dry air rich in ozone and PV from the upper troposphere/lower stratosphere to the lower troposphere is nicely illustrated from the latitude-pressure and longitude-pressure cross sections (centred over Crete) in Fig. 5. Specifically, the ERA-Interim July-August latitudepressure cross sections at a longitude of $24.5^{\circ} \mathrm{E}$ show a north-south descending structure of higher ozone (Fig. 5a), high PV (Fig. 5c) and lower SH (Fig. 5e) over the EMME. At the same time Fig. $5 \mathrm{~g}$ clearly shows the strong subsidence throughout most of the tropospheric column accompanied by persistent north-westerly flow in the middle and lower free troposphere and almost northerly flow within the boundary layer. This large-scale subsidence over the region from the upper to lower troposphere accompanied by the north-westerly advection and the limited divergence for the largest part of the tropospheric column accounts for the descending structures of ozone, PV and SH. Similarly, the respective longitude-pressure cross sections at a latitude of $35.25^{\circ} \mathrm{N}$ (Fig. 5b, d, f and h) illustrate the large-scale transport mechanisms controlling atmospheric composition over the $\mathrm{EM}\left(20^{\circ} \mathrm{E}\right.$ to $\left.40^{\circ} \mathrm{E}\right)$, in contrast to the central and western Mediterranean.

Hence, the links between ozone, potential vorticity and water vapour mixing ratios provide evidence that the dominant mechanism for the free-tropospheric ozone pool is the downward transport from the upper troposphere and lower stratosphere, associated with enhanced subsidence, northwesterly advection and limited horizontal divergence, which dominate over the summertime EMME. It should be emphasized that the above-mentioned ERA-Interim results for the 
a) July-August ERA-interim 03 (ppbv) at $700 \mathrm{hPa}$

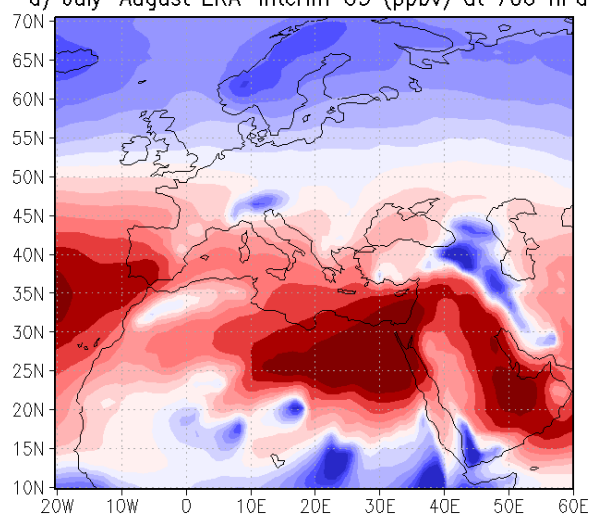

b) July-August ERA-interim 03 (ppbv) at $500 \mathrm{hPo}$

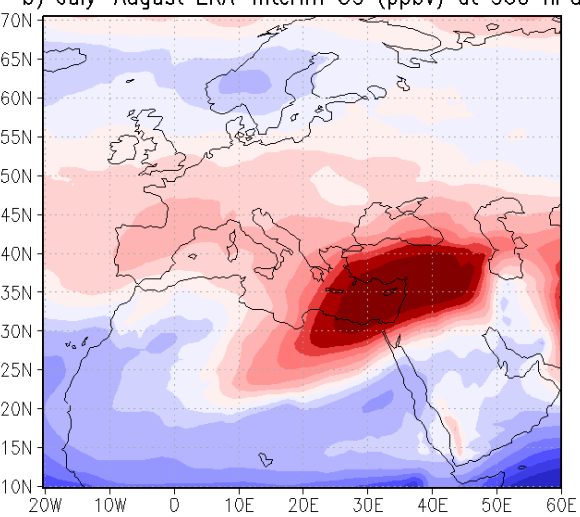

c) July-August ERA-interim 03 (ppbv) at $250 \mathrm{hPo}$

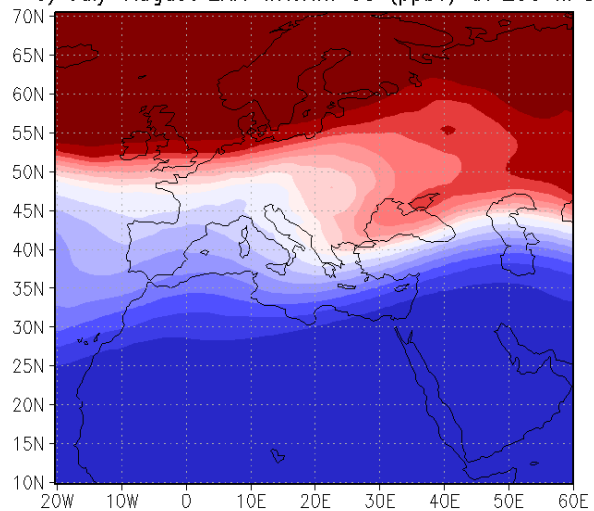

d) July-August ERA-interim PV (pvu) at $700 \mathrm{hPa}$
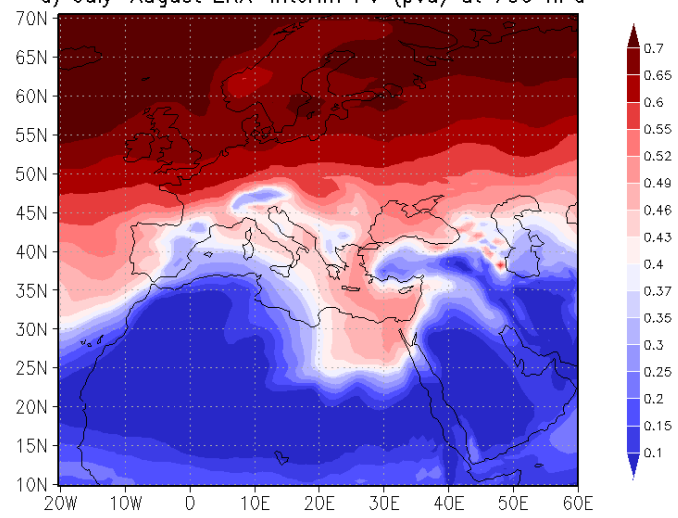

e) July-August ERA-interim PV (pvu) ot $500 \mathrm{hPo}$

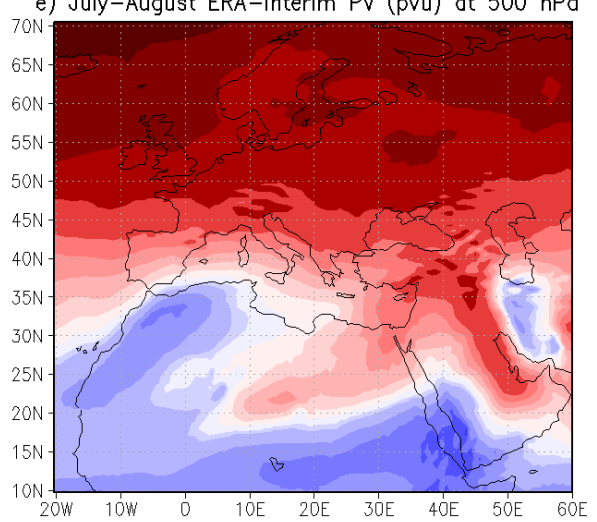

f) July-August ERA-interim PV (pvu) at $250 \mathrm{hPo}$

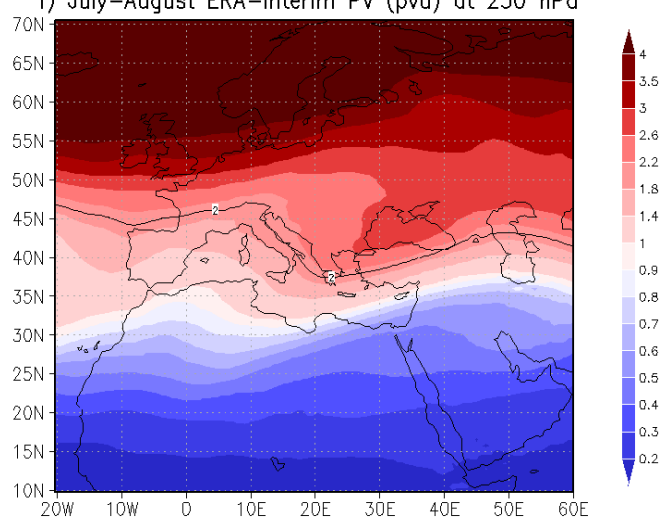

Fig. 4. ERA-Interim July-August average fields of ozone (ppbv), potential vorticity (pvu), specific humidity $\left(\mathrm{g} \mathrm{kg}^{-1}\right)$ and vertical velocity $\left(\mathrm{Pa} \mathrm{s}^{-1}\right.$ ) over the period 1998-2009 at $700 \mathrm{hPa}(\mathbf{a}, \mathbf{d}, \mathbf{g}, \mathbf{j})$, at $500 \mathrm{hPa}(\mathbf{b}, \mathbf{e}, \mathbf{h}, \mathbf{k})$ and at $250 \mathrm{hPa}(\mathbf{c}, \mathbf{f}, \mathbf{i}, \mathbf{l})$, respectively. The vectors in $(\mathbf{j})$, (k) and (l) denote the horizontal vectors based on the zonal and meridional wind components, while the contour lines indicate the respective average values of horizontal divergence $\left(10^{-5} \mathrm{~s}^{-1}\right)$.

period 1998-2009 are robust, being similar for the extended time period 1979-2009. Furthermore it should be noted that the subsidence over the EM during summer is a persistent feature from year to year.

\subsection{EMAC results}

The EMAC-simulated July-August average ozone fields (1998-2009) in the middle $(486 \mathrm{hPa})$ and lower free troposphere $(714 \mathrm{hPa})$ are shown in Fig. 6a and b, respectively, and illustrate the pool of high ozone values over the EMME, in agreement with the ERA-Interim results. To quantify the 

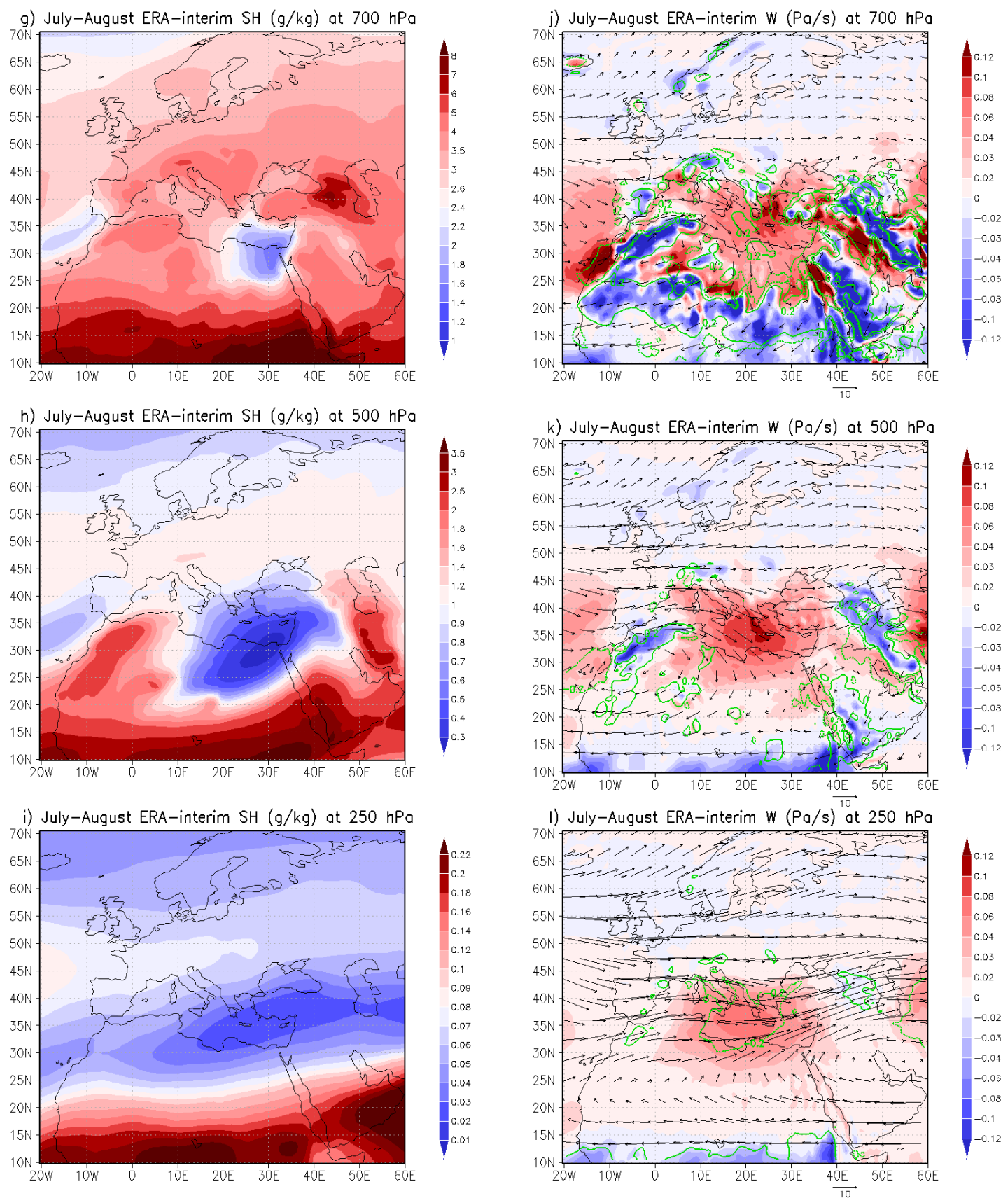

Fig. 4. Continued.

contribution of stratospheric ozone to these elevated tropospheric ozone values in the middle and lower free troposphere, the simulated in EMAC stratospheric ozone tracer (O3s) was investigated. The July-August average fields of the EMAC-simulated O3s clearly illustrate (Fig. 6c) a structure of high values (up to $42 \mathrm{ppbv}$ ) in the middle troposphere over the EM and Asia Minor, which actually also extend geographically to central Asia (east of the Caspian Sea). This structure of high O3s values corresponds to around 40-45\% of the ozone in the middle troposphere. Furthermore, in the lower free troposphere (Fig. 6d), the EMAC simulations also clearly indicate a pool of high O3s over the EMME (up to around $26 \mathrm{ppbv}$ ) which corresponds to around $30-35 \%$ of the ozone in the lower free troposphere. At the top of the boundary layer (at $850 \mathrm{hPa}$ ) O3s contributes around $16-20 \%$ of the tropospheric ozone over the EMME (not shown). The model results indicate the important contribution of stratospheric ozone to the pool of high ozone values over the EMME down to the lower free troposphere. This free-tropospheric ozone pool is a persistent feature from year to year over the 

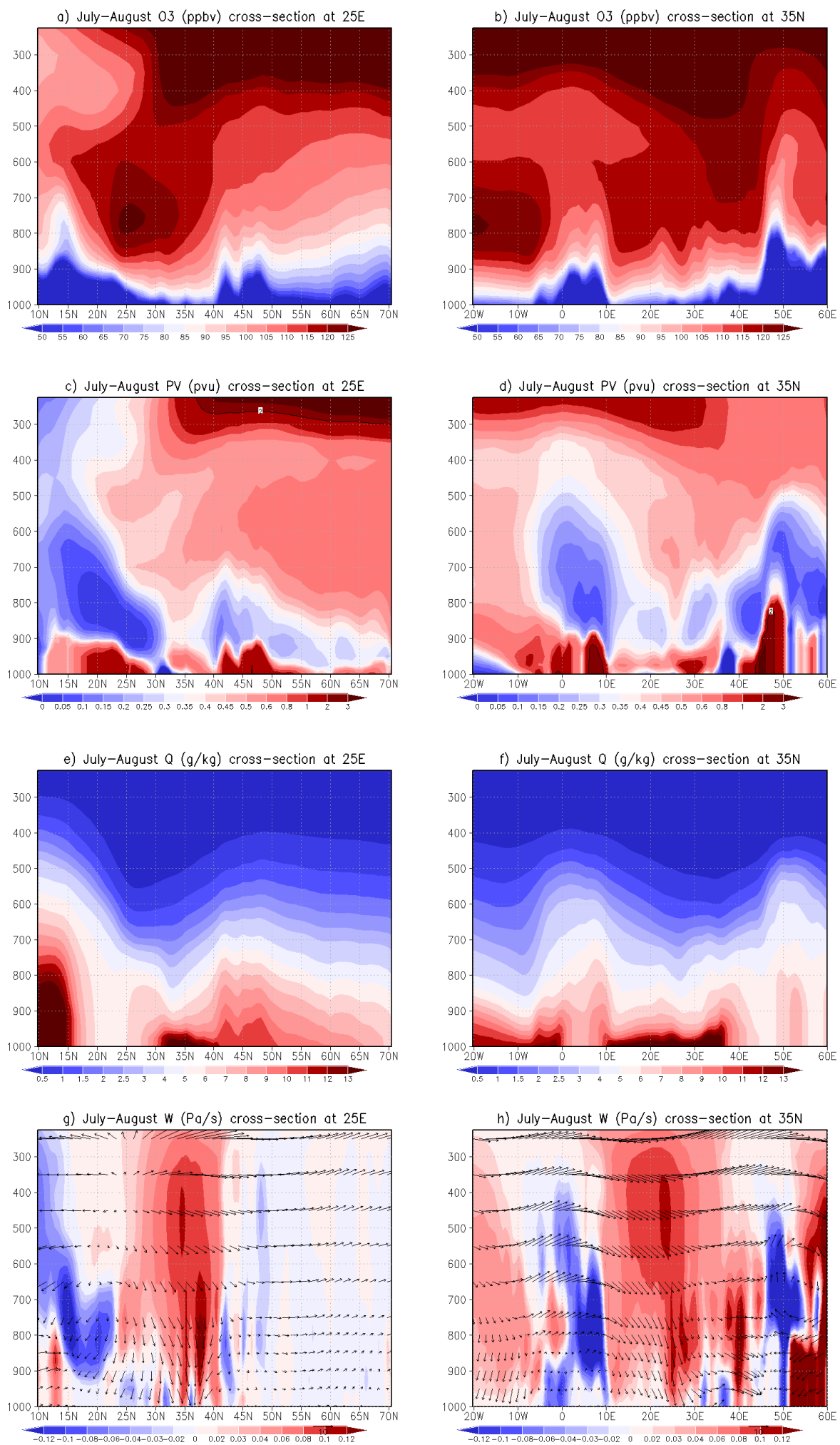

Fig. 5. Left column: ERA-Interim July-August latitude-pressure cross sections at longitude $24.5^{\circ}$ E of (a) ozone (ppbv), (c) potential vorticity (pvu), (e) specific humidity $\left(\mathrm{g} \mathrm{kg}^{-1}\right.$ ) and (g) vertical velocity $\left(\mathrm{Pa} \mathrm{s}^{-1}\right.$ ) averaged over the period 1998-2009. Right column: ERA-Interim July-August longitude-pressure cross sections at $35.25^{\circ} \mathrm{N}$ latitude of (b) ozone (ppbv), (d) potential vorticity (pvu), (f) specific humidity $\left(\mathrm{g} \mathrm{kg}^{-1}\right)$ and (h) vertical velocity $\left(\mathrm{Pa} \mathrm{s}^{-1}\right.$ ) averaged over the period 1998-2009. The solid black line in (c) denotes the dynamical tropopause at 2 pvu. The vectors in (g) and (h) denote the horizontal vectors based on the zonal and meridional wind components. 

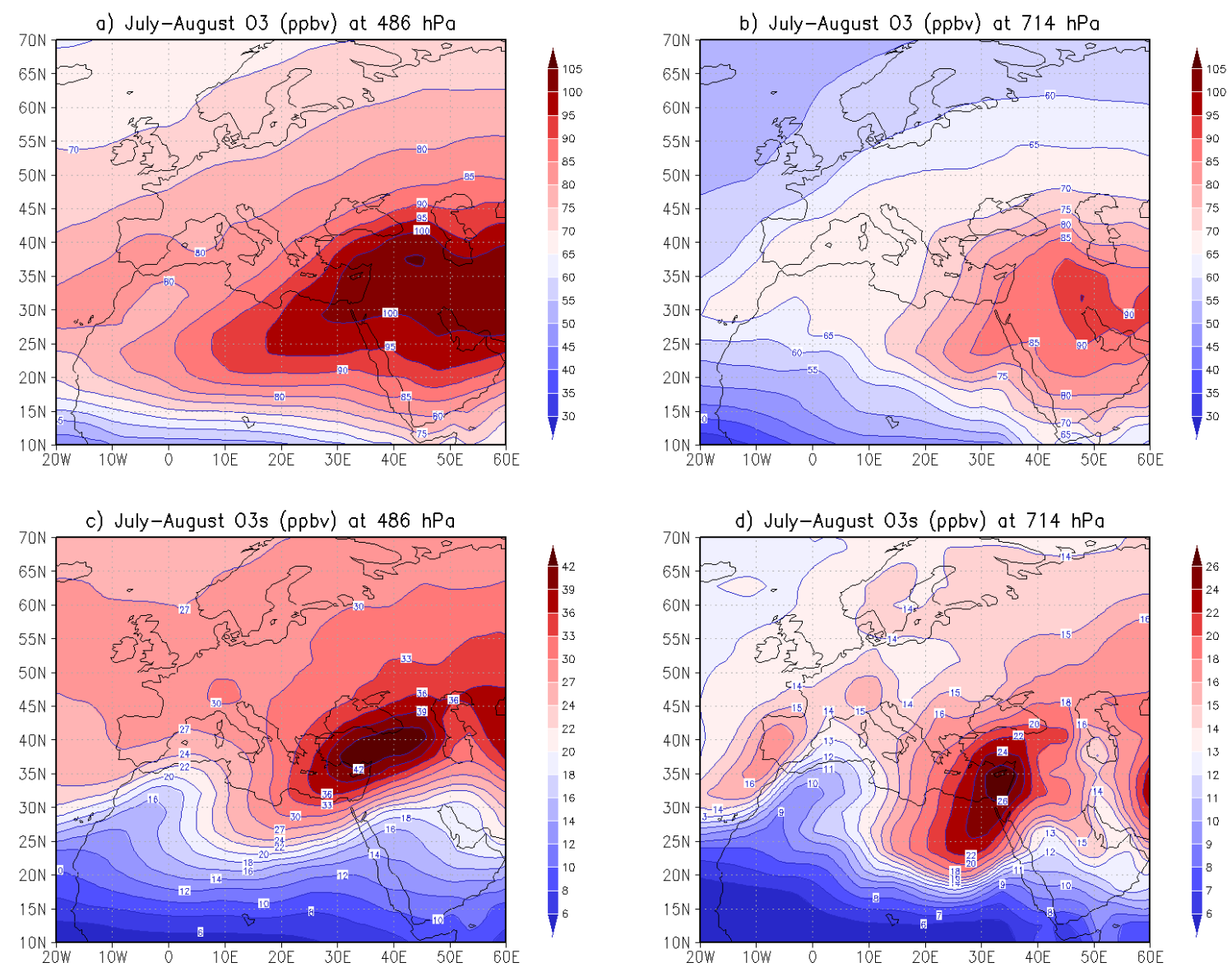

Fig. 6. EMAC July-August average fields of simulated ozone (ppbv) and the stratospheric ozone tracer O3s (ppbv) over the period 1998-2009 at $486 \mathrm{hPa}(\mathbf{a}, \mathbf{c})$ and at $714 \mathrm{hPa}(\mathbf{b}, \mathbf{d})$, respectively.

EM in EMAC simulations. Nevertheless it should be pointed out that photochemical processes dominate for the control of ozone in the lower free troposphere and hence photochemical produced ozone in the free troposphere can be more important than ozone of stratospheric origin for affecting nearsurface ozone.

The downward transport of EMAC-simulated ozone and the stratospheric ozone tracer from lower stratosphere/upper troposphere is further illustrated from the latitude-pressure and longitude-pressure cross sections in Fig. 7. The average July-August latitude-pressure cross sections at a longitude of $25^{\circ} \mathrm{E}$ show a north-south descending structure of high ozone (Fig. 7a) and O3s (Fig. 7b) from the upper into the lower tropospheric levels (down to $800 \mathrm{hPa}$ ), in agreement with the ERA-Interim analysis (Fig. 5). A similar picture emerges from the respective longitude-pressure cross sections at a latitude of $35^{\circ} \mathrm{N}$ (Fig. 7c, d). Figure 7 also illustrates the different impacts of downward transport of the stratospheric ozone tracer between the eastern and centralwestern Mediterranean. In general, the investigation of the EMAC simulations reveals the downward transport pathway and corroborates the significant contribution of stratospheric ozone to the pool of high ozone values over the EMME in the middle and lower free troposphere, in agreement with the ERA-Interim analysis (see Sect. 3.2).

\subsection{Implications for the near-surface ozone in Mediterranean}

The middle/lower troposphere ozone pool over the EMME may have important implications for the spatial distribution of the near-surface ozone over the Mediterranean. It was pointed out earlier that there is a difference between the eastern and central-western Mediterranean concerning the downward transport of stratospheric ozone associated with the enhanced subsidence that dominates over the EMME. This leads to highest ozone in the middle and lower free troposphere over the EMME during summer, illustrated by ERAInterim, TES and EMAC data. Here we discuss the possible implications for the seasonal cycle of the near-surface ozone in the Mediterranean Basin. We selected four EMEP baseline maritime ozone stations along the Mediterranean Basin (Fig. 1). From the EMAC-simulated ozone and O3s data, the closest grid cells to the stations' coordinates were selected. 
a) July-August 03 (ppbv) cross-section ot $25 E$

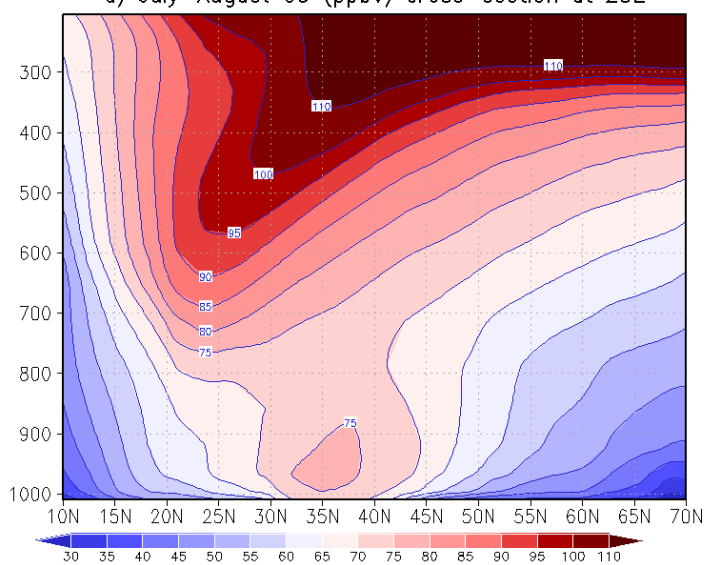

c) July-August 03 (ppbv) cross-section at $35 \mathrm{~N}$

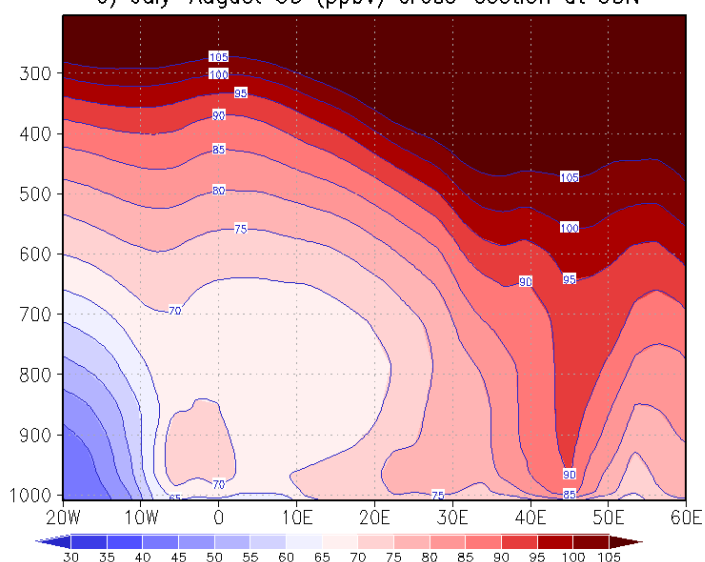

b) July-August $03 \mathrm{~s}$ (ppbv) cross-section at $25 \mathrm{E}$

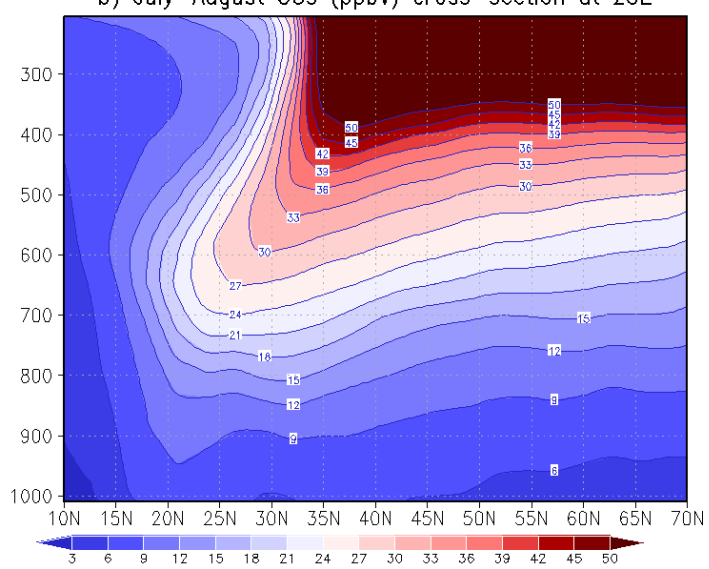

d) July-August $03 \mathrm{~s}$ (ppbv) cross-section at $35 \mathrm{~N}$

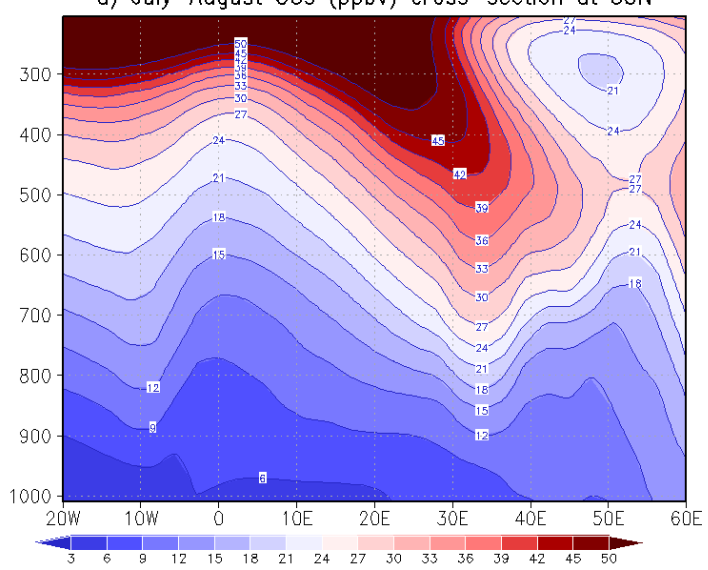

Fig. 7. Upper plates: EMAC July-August latitude-pressure cross sections at $25^{\circ} \mathrm{E}$ longitude of simulated (a) ozone (ppbv) and (b) stratospheric ozone tracer O3s (ppbv) averaged over the period 1998-2009. Bottom plates: EMAC July-August longitude-pressure cross sections at $35^{\circ} \mathrm{N}$ latitude of (c) ozone (ppbv) and (d) stratospheric ozone tracer (ppbv) averaged over the period 1998-2009.

The EMAC-simulated ozone in the lower free troposphere $(714 \mathrm{hPa})$ illustrates a summer maximum over the EM stations at Cyprus (CY02) and Crete (GR02) peaking in JulyAugust and broad spring-summer maximum at Gozo, Malta (MT01), over the central Mediterranean and Cabo de Creus, Spain (ES10), over the western Mediterranean (Fig. 8a). The highest summertime values of ozone in the lower free troposphere simulated by the EMAC model are located over the easternmost station at Cyprus (Fig. 8a), confirming the enhanced subsidence over this region with respect to the western and central Mediterranean. This distinction in the seasonal cycle of the modelled lower free-tropospheric ozone with higher values during summer over the EMME is due to the predominant contribution of stratospheric ozone (Fig. 8b). Figure 8b suggests a west-east gradient in the summertime $\mathrm{O} 3 \mathrm{~s}$ values across the Mediterranean Basin. Indeed, the lower free-tropospheric O3s values in August at CY02 and GR02 are $13 \mathrm{ppbv}$ and $8 \mathrm{ppbv}$ higher than at MT01 and ES10, respectively. The above results indicate the ability of the EMAC model to reproduce spatial characteristics of the summertime ozone distribution in the lower free troposphere over the Mediterranean Basin.

However, near the surface the distinction of O3s among the four stations in summer months (Fig. 8d) becomes small (about 1.5 to 2 ppbv higher at CY02 and GR02 than at MT01 and ES10). Furthermore, the four stations show similarities in the shape of near-surface modelled seasonal ozone cycle with a broad spring-summer maximum peaking in August (Fig. 8c). This result implies that photochemical processes dominate over downward transport processes in the seasonal ozone cycle in the Mediterranean boundary layer in the EMAC simulations.

The observed near-surface ozone seasonal cycles at the four stations (Fig. 8e) show some similarities and some differences to the modelled ones. The EMAC model clearly overestimates ozone at all four stations during the summer months, typically by about 10 to $20 \mathrm{ppbv}$ (20-35\%), as is illustrated in Fig. 8f. This is attributed to overestimated photochemical ozone production in the boundary layer in the EMAC simulations during summer. This is further illustrated 

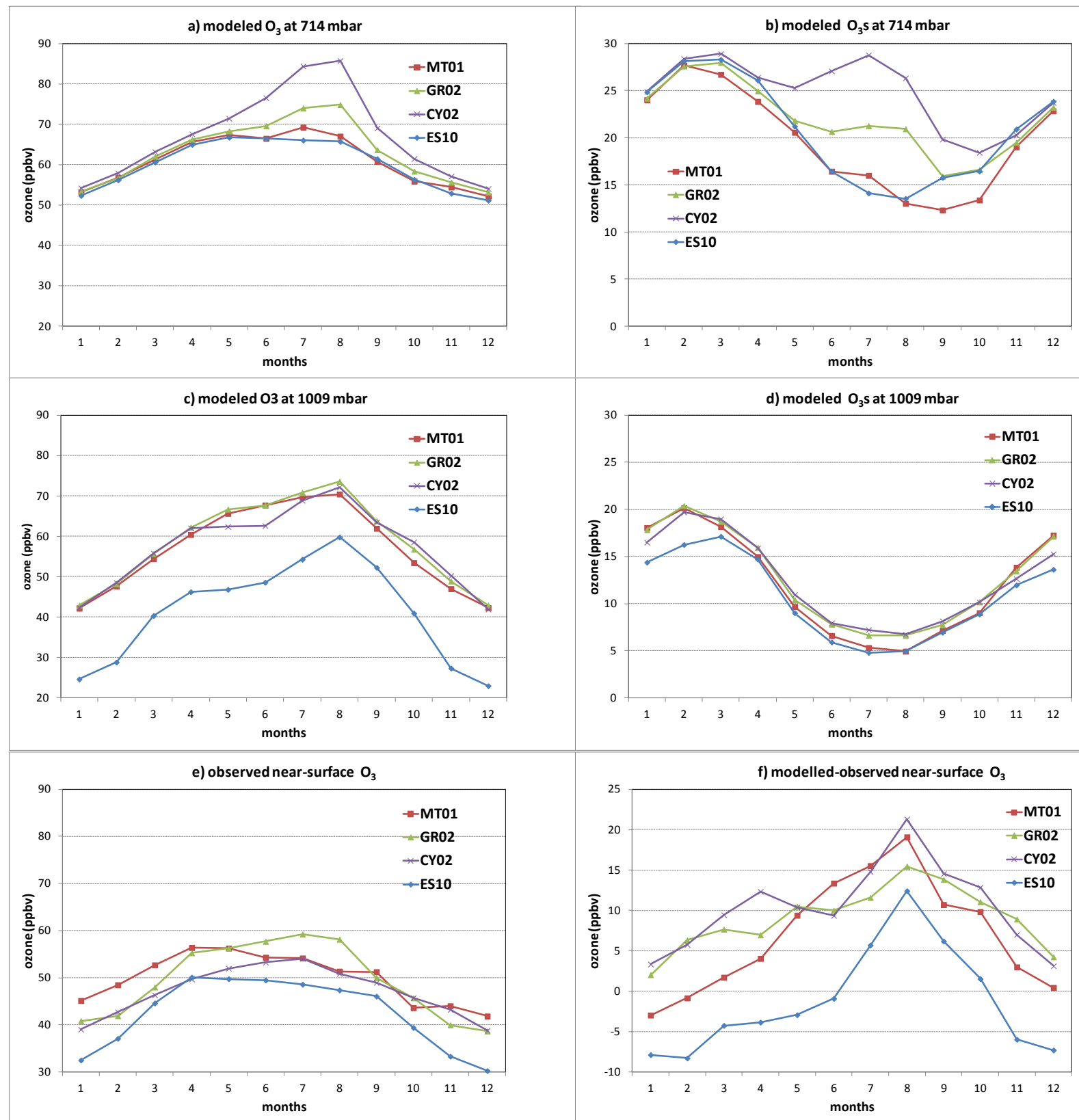

Fig. 8. Mean seasonal cycle over the period 1998-2008 of EMAC-simulated ozone (ppbv) and stratospheric ozone tracer O3s (ppbv) at $714 \mathrm{hPa}(\mathbf{a}, \mathbf{b})$ and at $1009 \mathrm{hPa}(\mathbf{c}, \mathbf{d})$ as well as observed near-surface ozone (e) and the difference between modelled and observed nearsurface ozone values (f) at the stations Gozo, Malta (MT01, red); Finokalia, Greece (GR02, green); Ag. Marina, Cyprus (CY02, purple); and Cabo de Creus, Spain (ES10, light blue). For the EMAC-simulated data the closest grid cell to the station coordinates was selected.

by the larger amplitude of the seasonal cycle of near-surface ozone in EMAC compared to observations and the fact that the model bias (modelled-observed near-surface ozone monthly values) has a seasonal behaviour with the highest biases attained during summer (Fig. 8f). This discrepancy is related to the coarse horizontal grid resolution of the model version used (250-300 km), which artificially mixes ozone precursors, notably $\mathrm{NO}_{\mathrm{x}}$, over a large volume, whereas in reality $\mathrm{NO}_{\mathrm{x}}$ transport from pollution sources to these background stations is limited by its short atmospheric lifetime in summer. As a consequence, the fractional contribution by the in situ-produced ozone is overestimated and the contribution by $\mathrm{O} 3 \mathrm{~s}$ is underestimated. The coarse horizontal resolution of EMAC has been a compromise to allow for high vertical resolution in the stratosphere and upper troposphere. Future work should consider increased horizontal resolution. 
Nevertheless, the shape of the seasonal cycle, e.g. the observed near-surface ozone maximum at GR02 in JulyAugust, is reproduced by the model, while at CY02 there is a slight difference as it peaks in July (observations) rather than in July-August (model values). Over MT01 and ES10 there is a distinct ozone spring maximum in the observations, which is in better agreement with the modelled ozone cycle in the lower free troposphere (at $714 \mathrm{hPa}$ ) than at the surface. Again the discrepancy between observations and model at the surface is explained by the overestimated photochemical ozone formation within the boundary layer by EMAC, associated with long-distance transport of $\mathrm{NO}_{\mathrm{x}}$ and other precursor gases from the polluted European continent toward the considered marine background stations, which masks the contribution of downward transport.

As pointed out earlier, the free-tropospheric ozone pool is a persistent feature from year to year over EMME in EMAC simulations. Looking into the year-to-year relation between the free-tropospheric ozone pool and near-surface ozone, we found that the mean July-August observed O3 values at GR02 correlates positively with the mean July-August modelled EMAC O3 and $\mathrm{O} 3 \mathrm{~s}$ values at $714 \mathrm{hPa}(\rho=0.53$ and $\rho=0.57$, respectively) over the period 1998-2008. These positive correlations imply that the interannual variability of the near-surface ozone over the EM is related to the interannual variability of the free-tropospheric ozone pool and the stratospheric ozone tracer. Future work is needed to investigate the interannual variability of the summer circulation and the free-tropospheric ozone pool and how it is related to the interannual variability of the near-surface ozone over the EMME.

\section{Discussion and conclusions}

A $12 \mathrm{yr}$ climatological analysis (1998-2009) of freetropospheric ozone was carried out based on the ERAInterim reanalysis data and simulations with the EMAC atmospheric chemistry-climate model nudged towards ECMWF analysis data. A characteristic summertime pool of high ozone concentrations is found in the middle troposphere over the EMME in the ERA-Interim ozone data. This characteristic pool of high ozone in the middle troposphere over the EMME is also present in the TES ozone profiles (2005-2009) and further supported by EMAC simulations. The EMAC model adequately resolves the region around the tropopause and it includes a stratospheric ozone tracer to facilitate the investigation of stratospheric contributions to tropospheric ozone.

The middle-troposphere summertime ozone pool over the EMME has been mentioned previously in a number of observational and modelling studies (e.g. Marenco et al., 1998; Stohl et al., 2001; Jonson et al., 2001; Li et al., 2001; Roelofs et al., 2003; Liu et al., 2009). The analysis of ERA-Interim data and EMAC results corroborate that the enhanced ozone over the EMME is a robust feature, propagating downward to lower free-tropospheric levels.

The links of ozone with other transport tracers such as PV and specific humidity indicate that the dominant mechanism for the free-tropospheric ozone pool is downward transport from the upper troposphere and lower stratosphere associated with the enhanced subsidence and limited horizontal divergence that characterize the summertime EMME circulation. It was shown that the region with the highest subsidence is located on the western flank of the higher PV streamers extending southwards, implying co-location of the region with the strongest subsidence and the region of maximum STT. According to the study of Sprenger et al. (2007) the STT maximum is found on the western flank of the stratospheric PV streamers. It should be pointed out that as we move to lower tropospheric levels, the location of the ozone maximum shifts towards the south-eastern Mediterranean, downstream from the areas of strongest subsidence, in association with the persistent north-westerly to northerly flow for the middle and lower free troposphere which is related to the nearly isentropic sloping and downgliding of the air masses towards the Levantine region.

Furthermore the EMAC simulations indicate the large contribution of stratospheric ozone to the pool of high ozone values over EMME in the middle and lower free troposphere. Traub and Lelieveld (2003) investigated the cross-tropopause transport over the EM by analysing trajectories for the MINOS campaign (August 2001) and found from analysis of the residence times in the stratosphere and troposphere after crossing the tropopause (set at 3.5 PVU) that the transport is vertically shallow and that this mixing of tropospheric and stratospheric air is largely confined to the upper troposphere during summer. According to the study of Sprenger and Wernli (2003), the geographical distribution of the downward (STT) cross-tropopause exchange mass in summer shows maxima occurring to the north of the EMME region, over the continental mid-latitudes of Europe and Asia. Sprenger et al. (2007) showed that the most of the STT events are rather shallow on short timescales, with most of the stratospheric tracer mass remaining in the upper troposphere over periods of up to a few days. The more deeply intruded the air, the greater the age of the stratospheric air, which is subsequently embedded into the large-scale general circulation. The contribution of the rare deep STT events (lower than $3 \mathrm{~km}$ ) should not be disregarded since the EM is a favourable destination region of deep STT events, as has been shown in both case studies (Zanis et al., 2003; Galani et al., 2003; Papayannis et al., 2005; Gerasopoulos et al., 2006a; Akritidis et al., 2010) and climatological studies (Sprenger and Wernli, 2003; James et al., 2003). In the study of James et al. (2003) it is shown that the EM (e.g. see their Fig. 4) is a favourable destination region not only of deep STT events but also of medium and shallow STT events affecting the whole tropospheric column over the area during summer. Recently, Tyrlis et al. (2013b) indicated a global "hot spot" of summertime 
tropopause fold activity over a sector between the eastern Mediterranean and Afghanistan, in the vicinity of the subtropical jet, with the rare deeper folds penetrating towards the Levantine region.

Taking into account the above results we infer that STT processes feed stratospheric ozone into the upper troposphere, and subsequently these ozone-rich air masses are transported to the lower free-tropospheric levels through the characteristic strong summertime EMME subsidence at the western flank of the higher PV streamers extending southwards and in association also with the persistent northwesterly to northerly flow for the middle and lower troposphere.

Furthermore, it should be pointed out that upper- and middle-tropospheric ozone levels can be additionally enriched by accumulated ozone production from tropospheric photochemical processes on the hemispheric scale during summertime over the Middle East and northern Africa (Liu et al., 2009). Our results are in agreement with the findings of Kalabokas et al. (2007, 2013), who concluded that the highest ozone concentrations in the lower troposphere over the EM and subsequently within the boundary layer are associated with large-scale subsidence of ozone-rich air masses from the upper troposphere. Several years of ozone records at different Greek stations as well as ozone measurements along the Aegean Sea from an intensive ship campaign showed spatial homogeneity with comparably high ozone levels to Finokalia during summer (Kouvarakis et al., 2002; Kalabokas et al., 2008), thus indicating the importance of large-scale subsidence for the near-surface ozone over the area.

Our results are also in agreement with Roelofs et al. (2003), who showed substantial contributions to elevated ozone in the middle troposphere by transport from the stratosphere. Furthermore, our findings are partially in line with the study of Li et al. (2001), who concluded that large-scale subsidence over the region with continuous net production of ozone and limited mid-level divergence is a major mechanism, but in contrast to our results, they deduced that transport from the stratosphere does not contribute significantly to the ozone maximum. This substantiates the need to apply a model that realistically simulates stratosphere-troposphere exchange processes (in the present work at the expense of horizontal resolution near the surface).

The differences in the seasonal cycle of the modelled lower free-tropospheric ozone across the Mediterranean Basin (with highest values during summer towards the east) indicate the ability of the EMAC model to reproduce notable spatial characteristics of the ozone distribution in the lower free troposphere over the region. This is a consequence of the emphasis of the selected EMAC version to accurately reproduce the dynamical processes around the tropopause. In support of this, it should be noted that simulations with a regional air quality model (CAMx) showed an underestimation of surface ozone during summer at baseline stations over the EM due to the limited vertical domain (top at around $6 \mathrm{~km}$ ) and hence the lack of realistic middle-tropospheric conditions to simulate the effects of subsidence on near-surface ozone (Akritidis et al., 2013).

However, within the atmospheric boundary layer, longdistance pollution transport and photochemical processes dominate over downward ozone transport in EMAC simulations. The overestimate of $\mathrm{NO}_{\mathrm{x}}$ and other ozone precursor transport from the European continent due to the coarse horizontal resolution of the EMAC model leads to a rather spatially uniform seasonal ozone cycle over the Mediterranean Basin. This result is not supported by the EMEP observations, which show a seasonal cycle peaking in summer for the EM stations and a seasonal cycle peaking in spring for the central and western Mediterranean stations (Fig. 8e). The discrepancy between EMAC and observed ozone near the surface is attributed to overestimated modelled photochemical ozone production during summer related to the coarse horizontal resolution, thus partially masking the contribution of downward transport, which is stronger over the EM than over the central and western Mediterranean. Furthermore, it is important to accurately resolve boundary layer processes because the representation of entrainment from the lower free troposphere is expected to be important as well. For example, based on observations, Gerasopoulos et al. (2006b) showed that the dominating factor for the maximum ozone values during summer at Finokalia station is the entrainment of ozone-rich air masses from the free troposphere.

Therefore, it is suggested that model studies focusing on tropospheric ozone over the EMME region should realistically represent both stratosphere-troposphere exchange processes and boundary layer transport and photochemistry at high horizontal and vertical resolution.

Acknowledgements. The research leading to these results has received funding from the European Research Council under the European Union's Seventh Framework Programme (FP7/20072013) / ERC grant agreement no. 226144. Part of the study was supported within the framework of the Greece-Germany Exchange and Cooperation Programme, IKY-DAAD 2012. The authors would like also to thank the two reviewers for their constructive comments.

Edited by: P. Monks

\section{References}

Akritidis, D., Zanis, P., Pytharoulis, I., Mavrakis, A., and Karacostas, Th.: A deep stratospheric intrusion event down to the earth's surface of the megacity of Athens, Meteorol. Atmos. Phys., 109, 9-18, doi:10.1007/s00703-010-0096-6, 2010.

Akritidis, D., Zanis, P., Katragkou, E., Schultz, M., Tegoulias, I., Poupkou, A., Markakis, K., Pytharoulis, I., and Karacostas, Th.: Evaluating the impact of chemical boundary conditions on near surface ozone in regional climate-air quality simulations over Europe, Atmos. Res., 134, 116-130, doi:10.1016/j.atmosres.2013.07.021, 2013. 
Anagnostopoulou, C., Zanis, P., Katragkou, E., Tegoulias, I., and Tolika, K.: Recent past and future patterns of the Etesian winds based on regional scale climate model simulations, Clim. Dynam., doi:10.1007/s00382-013-1936-0, in press, 2013.

Beer, R.: TES on the Aura Mission: scientific objectives, measurements and analysis overview, IEEE T. Geosci. Remote, 44, 11021105, 2006.

Beer, R., Glavich, T. A., and Rider, D. M.: Tropospheric Emission Spectrometer for the Earth Observing System's Aura satellite, Appl. Optics, 40, 2356-2367, 2001.

Berrisford, P., Kållberg, P., Kobayashi, S., Dee, D., Uppala, S., Simmons, A. J., Poli, P., and Sato, H.: Atmospheric conservation properties in ERA-Interim, Q. J. Roy. Meteor. Soc., 137, 13811399, doi:10.1002/qj.864, 2011.

Cariolle, D. and Déqué, M.: Southern hemisphere medium-scale waves and total ozone disturbances in a spectral general circulation model, J. Geophys. Res., 91, 10825-10846, 1986.

Cariolle, D. and Teyssèdre, H.: A revised linear ozone photochemistry parameterization for use in transport and general circulation models: multi-annual simulations, Atmos. Chem. Phys., 7, 21832196, doi:10.5194/acp-7-2183-2007, 2007.

Chameides, W. and Walker, J. C. G.: A photochemical theory of tropospheric ozone, J. Geophys. Res., 78, 8751-8760, 1973.

Crutzen, P. J.: Tropospheric ozone: An overview, in: Tropospheric Ozone, edited by: Isaksen, I. S. A., D. Reidel Publ. Co., 3-32, 1988.

Crutzen, P. J., Lawrence, M. G., and Poeschl, U.: On the background photochemistry of tropospheric ozone, Tellus A, 51, 123-146, 1999.

Dee, D. P., Uppala, S. M., Simmons, A. J., Berrisford, P., Poli, P., Kobayashi, S., Andrae, U., Balmaseda, M. A., Balsamo, G., Bauer, P., Bechtold, P., Beljaars, A. C. M., van de Berg, L., Bidlot, J., Bormann, N., Delsol, C., Dragani, R., Fuentes, M., Geer, A. J., Haimberger, L., Healy, S. B., Hersbach, H., Hólm, E. V., Isaksen, L., Kållberg, P., Köhler, M., Matricardi, M., McNally, A. P., Monge-Sanz, B. M., Morcrette, J.-J., Park, B.-K., Peubey, C., de Rosnay, P., Tavolato, C., Thépaut, J.-N., and Vitart, F.: The ERA-Interim reanalysis: configuration and performance of the data assimilation system, Q. J. Roy. Meteor. Soc., 137, 553-597, doi:10.1002/qj.828, 2011.

Dethof, A. and Hólm, E.: Ozone assimilation in the ERA-40 reanalysis project, Q. J. Roy. Meteor. Soc., 130, 2851-2872, 2004.

Dragani, R.: On the quality of the ERA-Interim ozone reanalyses: comparisons with satellite data, Q. J. Roy. Meteor. Soc., 137, 1312-1326, doi:10.1002/qj.821, 2011.

Galani, E., Balis, D., Zanis, P., Zerefos, C., Papayannis, A., Wernli, H., and Gerasopoulos, E.: Observations of stratospheretroposphere transport events over the eastern Mediterranean using a ground-based lidar system, J. Geophys. Res., 108, 8527, doi:10.1029/2002JD002596, 2003.

Gerasopoulos, E., Kouvarakis, G., Vrekoussis, M., Kanakidou, M., and Mihalopoulos, N.: Ozone variability in the marine boundary layer of the Eastern Mediterranean based on 7-year observations, J. Geophys. Res., 110, D15309, doi:10.1029/2005JD005991, 2005.

Gerasopoulos, E., Zanis, P., Papastefanou, C., Zerefos, C. S., Ioannidou, A., and Wernli, H.: A complex case study of down to the surface intrusions of persistent stratospheric air over the Eastern Mediterranean, Atmos. Environ., 40, 4113-4125, 2006a.
Gerasopoulos, E., Kouvarakis, G., Vrekoussis, M., Donoussis, C., Mihalopoulos, N., and Kanakidou, M.: Photochemical ozone production in the Eastern Mediterranean, Atmos. Environ., 40, 3057-3069, doi:10.1016/j.atmosenv.2005.12.061, 2006b.

Holton, J. R., Haynes, P. H., McIntyre, E. M., Douglass, A. R., Rood, R. B., and Pfister, L.: Stratosphere-troposphere exchange, Rev. Geophys., 33, 403-439, 1995.

Hoskins, B. J., McIntyre, M. E., and Robertson, A. W. : On the use and significance of isentropic potential vorticity maps, Q. J. Roy. Meteor. Soc., 111, 877-946, 1985.

Im, U., Markakis, K., Poupkou, A., Melas, D., Unal, A., Gerasopoulos, E., Daskalakis, N., Kindap, T., and Kanakidou, M.: The impact of temperature changes on summer time ozone and its precursors in the Eastern Mediterranean, Atmos. Chem. Phys., 11, 3847-3864, doi:10.5194/acp-11-3847-2011, 2011.

IPCC, Climate change 2007: The physical science basis. Contribution of Working Group I to the Fourth Assessment Report of the Intergovernmental Panel on Climate Change, in: Cambridge University Press, edited by: Solomon, S., Qin, D., Manning, M., Chen, Z., Marquis, M., Averyt, K. B., Tignor, M., and Miller, H. L., Cambridge, United Kingdom and New York, NY, USA, 996 pp., 2007.

James, P., Stohl, A., Forster, C., Eckhardt, S., Seibert, P., and Frank, A.: A 15-year climatology of stratosphere-troposphere exchange with a Lagrangian particle dispersion model, 2, Mean climate and seasonal variability, J. Geophys. Res., 108, 8522, doi:10.1029/2002JD002639, 2003.

Jöckel, P., Sander, R., Kerkweg, A., Tost, H., and Lelieveld, J.: Technical Note: The Modular Earth Submodel System (MESSy) - a new approach towards Earth System Modeling, Atmos. Chem. Phys., 5, 433-444, doi:10.5194/acp-5-433-2005, 2005.

Jöckel, P., Tost, H., Pozzer, A., Brühl, C., Buchholz, J., Ganzeveld, L., Hoor, P., Kerkweg, A., Lawrence, M. G., Sander, R., Steil, B., Stiller, G., Tanarhte, M., Taraborrelli, D., van Aardenne, J., and Lelieveld, J.: The atmospheric chemistry general circulation model ECHAM5/MESSy1: consistent simulation of ozone from the surface to the mesosphere, Atmos. Chem. Phys., 6, 50675104, doi:10.5194/acp-6-5067-2006, 2006.

Jöckel, P., Kerkweg, A., Pozzer, A., Sander, R., Tost, H., Riede, H., Baumgaertner, A., Gromov, S., and Kern, B.: Development cycle 2 of the Modular Earth Submodel System (MESSy2), Geosci Model Dev., 3, 717-752, doi:10.5194/gmd-3-717-2010, 2010.

Jonson, J. E., Sunder, J. K., and Tarrasón, L.: Model calculations of present and future levels of ozone and ozone precursors with a global and a regional model, Atmos. Environ., 35, 525-537, 2001.

Kalabokas, P. D. and Bartzis, J. G.: Photochemical air pollution characteristics at the station of the NCSR-Demokritos, during the MEDCAPHOT-TRACE campaign, Greece (20 August-20 September 1994), Atmos. Environ., 32, 2123-2139, 1998.

Kalabokas, P. D. and Repapis, C. C.: A climatological study of rural surface ozone in central Greece, Atmos. Chem. Phys., 4, 11391147, doi:10.5194/acp-4-1139-2004, 2004.

Kalabokas, P. D., Viras, L. G., Bartzis, J. G., and Repapis, C. C.: Mediterranean rural ozone characteristics around the urban area of Athens, Atmos. Environ., 34, 5199-5208, 2000.

Kalabokas, P. D., Volz-Thomas, A., Brioude, J., Thouret, V., Cammas, J.-P., and Repapis, C. C.: Vertical ozone measurements in the troposphere over the Eastern Mediterranean and 
comparison with Central Europe, Atmos. Chem. Phys., 7, 37833790, doi:10.5194/acp-7-3783-2007, 2007.

Kalabokas, P. D., Mihalopoulos, N., Ellul, R., Kleanthous, S., and Repapis, C. C.: An investigation of the meteorological and photochemical factors influencing the background rural and marine surface ozone levels in the Central and Eastern Mediterranean, Atmos. Environ., 42, 7894-7906, 2008.

Kalabokas, P. D., Cammas, J.-P., Thouret, V., Volz-Thomas, A., Boulanger, D., and Repapis, C. C.: Examination of the atmospheric conditions associated with high and low summer ozone levels in the lower troposphere over the eastern Mediterranean, Atmos. Chem. Phys., 13, 10339-10352, doi:10.5194/acp-1310339-2013, 2013

Kallos, G., Kotroni, V., Lagouvardos, K., and Papadopoulos, A.: On the long range transport of air pollutants from Europe to Africa, Geophys. Res. Lett., 25, 619-622, 1998.

Kanakidou, M., Mihalopoulos, N., Kindap, T., Im, U., Vrekoussis, M., Gerasopoulos, E., Dermitzaki, E., Unal, A., Koçak, M., Markakis, K., Melas, D., Kouvarakis, G., Youssef, A. F., Richter, A., Hatzianastassiou, N., Hilboll, A., Ebojie, F., Wittrock, F., von Savigny, C., Burrows, J. P., Ladstaetter-Weissenmayer, A., and Moubasher, H.: Megacities as hot spots of air pollution in the East Mediterranean, Atmos. Environ., 45, 1223-1235, doi:10.1016/j.atmosenv.2010.11.048, 2011.

Kourtidis, K., Ziomas, I., Zerefos, C., Balis, D., Suppan, P., Vassaras, A., Kosmidis, V., and Kentrarchos, A.: On the background ozone values in Greece. Seventh European Symposium on Physico-chemical Behaviour of Atmospheric Pollutants: The Oxidizing Capacity of the Troposphere, EUR 17482 EN, Venice, Italy, 456-461 pp., 1996.

Kourtidis, K., Zerefos, C., Rapsomanikis, S., Simeonov, V., Balis, D., Perros, P. E., Thomson A. M., Witte, J., Calpini, B., Sharobiem, W. M., Papayiannis, A., Mihalopoulos, N., and Drakou, R.: Regional levels of ozone in the troposphere over eastern Mediterranean, J. Geophys. Res., 107, 8140, doi:10.1029/2000JD000140, 2002.

Kouvarakis, G., Tsigaridis, K., Kanakidou, M., and Mihalopoulos, N.: Temporal variations of surface regional background ozone over Crete Island in the southeast Mediterranean, J. Geophys. Res., 105, 4399-4407, 2000.

Kouvarakis, G., Vrekoussis, M., Mihalopoulos, N., Kourtidis, K., Rappenglueck, B., Gerasopoulos, E., and Zerefos, C.: Spatial and temporal variability of tropospheric ozone in the boundary layer above the Aegean Sea (eastern Mediterranean), J. Geophys. Res., 107, 8137, doi:10.1029/2000JD000081, 2002.

Lacis, A. A., Wuebbles, D. J., and Logan, J. A.: Radiative forcing of climate by changes in the vertical distribution of ozone, J. Geophys. Res., 95, 9971-9981, 1990.

Lelieveld, J. and Dentener, F. J.: What controls tropospheric ozone?, J. Geophys. Res., 105, 3531-3551, 2000.

Lelieveld, J., Berresheim, H., Borrmann, S., Crutzen, P. J., Dentener, F. J., Fischer, H., de Gouw, J., Feichter, J., Flatau, P., Heland, J., Holzinger, R., Korrmann, R., Lawrence, M., Levin, Z., Markowicz, K., Mihalopoulos, N., Minikin, A., Ramanathan, V., de Reus, M., Roelofs, G.-J., Scheeren, H. A., Sciare, J., Schlager, H., Schultz, M., Siegmund, P., Steil, B., Stephanou, E., Stier, P., Traub, M., Williams, J., and Ziereis, H.: Global air Pollution crossroads over the Mediterranean, Science, 298, 794-799, 2002.
Lelieveld, J., Brühl, C., Jöckel, P., Steil, B., Crutzen, P. J., Fischer, H., Giorgetta, M. A., Hoor, P., Lawrence, M. G., Sausen, R., and Tost, H.: Stratospheric dryness: model simulations and satellite observations, Atmos. Chem. Phys., 7, 1313-1332, doi:10.5194/acp-7-1313-2007, 2007.

Lelieveld, J., Hoor, P., Jöckel, P., Pozzer, A., Hadjinicolaou, P., Cammas, J.-P., and Beirle, S.: Severe ozone air pollution in the Persian Gulf region, Atmos. Chem. Phys., 9, 1393-1406, doi:10.5194/acp-9-1393-2009, 2009.

Li, Q., Jacob, D. J., Logan, J. A., Bey, I., Yantosca, R. M., Liu, H., Martin, R. V., Fiore, A. M., Field, B. D, Duncan, B. N., and Thouret, V.: A tropospheric ozone maximum over the Middle East, Geophys. Res. Lett., 28, 3235-3238, doi:10.1029/2001GL013134, 2001.

Liakakou, E., Vrekoussis, M., Bonsang, B., Donousis, C., Kanakidou, M., and Mihalopoulos, N.: Isoprene above the Eastern Mediterranean: seasonal variation and contributionto the oxidation capacity of the atmosphere, Atmos. Environ., 41, 1002 1010, doi:10.1016/j.atmosenv.2006.09.034, 2007.

Liu, J. J., Jones, D. B. A., Worden, J. R., Noone, D., Parrington, M., and Kar, J.: Analysis of the summertime buildup of tropospheric ozone abundances over the Middle East and North Africa as observed by the Tropospheric Emission Spectrometer instrument, J. Geophys. Res., 114, D05304, doi:10.1029/2008JD010993, 2009.

Marenco, A., Thouret, V., Nédélec, P., Smit, H. G. J., Helten, M., Kley, D., Karcher, F., Simon, P., Law, K., Pyle, J., Poschmann, G., Von Wrede, R., Hume, C., and Cook, T.: Measurement of ozone and water vapor by Airbus in-service aircraft: The MOZAIC airborne program, An overview, J. Geophys. Res., 103, 25631-25642, doi:10.1029/98JD00977, 1998.

Osterman, G. B., Kulawik, S. S., Worden, H. M., Richards, N. A. D., Fisher, B. M., Eldering, A., Shephard, M. W., Froidevaux, L., Labow, G., Luo, M., Herman, R. L., Bowman, K. W., and Thompson, A. M.: Validation of Tropospheric Emission Spectrometer (TES) measurements of the total, stratospheric, and tropospheric column abundance of ozone, J. Geophys. Res., 113, D15S16, doi:10.1029/2007JD008801, 2008.

Papayannis, A., Balis, D., Zanis, P., Galani, E., Wernli, H., Zerefos, C., Stohl, A., Eckhardt, S., and Amiridis, V.: Sampling of an STT event over the Eastern Mediterranean region by lidar and electrochemical sonde, Ann. Geophys., 23, 2039-2050, doi:10.5194/angeo-23-2039-2005, 2005.

Penkett, S. A.: Indications and causes of ozone increase in the troposphere, in: The changing atmosphere, edited by: Rowland, F S. and Isaksen, I. S. A., J. Wiley \& Sons, 91 pp., 1988.

Poupkou, A., Zanis, P., Nastos, P., Papanastasiou, D., Melas, D., Tourpali, K., and Zerefos, C.: Present climate trend analysis of the Etesian winds in the Aegean Sea, Theor. Appl. Climatol., 106, 459-472, doi:10.1007/s00704-011-0443-7, 2011.

Pozzer, A., Jöckel, P., Tost, H., Sander, R., Ganzeveld, L., Kerkweg, A., and Lelieveld, J.: Simulating organic species with the global atmospheric chemistry general circulation model ECHAM5/MESSy1: a comparison of model results with observations, Atmos. Chem. Phys., 7, 2527-2550, doi:10.5194/acp-72527-2007, 2007.

Repapis, C., Zerefos, C., and Tritakis, B.: On the Etesians over the Aegean, Proc. Acad. Athens, 52, 572-606, 1977.

Richards, N. A. D., Arnold, S. R., Chipperfield, M. P., Miles, G., Rap, A., Siddans, R., Monks, S. A., and Hollaway, M. J.: 
The Mediterranean summertime ozone maximum: global emission sensitivities and radiative impacts, Atmos. Chem. Phys., 13, 2331-2345, doi:10.5194/acp-13-2331-2013, 2013.

Rodwell, M. J. and Hoskins, B. J.: Monsoons and the dynamics of deserts, Q. J. Roy. Meteor. Soc., 122, 1385-1404, 1996.

Rodwell, M. J. and Hoskins, B. J.: Subtropical Anticyclones and Summer Monsoons, J. Climate, 14, 3192-3211, 2001.

Roeckner, E., Brokopf, R., Esch, M., Giorgetta, M., Hagemann, S., Kornbluh, Manzini, L. E., Schlese, U., and Schulzweida, U.: Sensitivity of simulated climate to horizontal and vertical resolution in the ECHAM5 atmosphere model, J. Climate, 19, 3771-3791, 2006.

Roelofs, G. J. and Lelieveld, J.: Model study of the influence of cross-tropopause $\mathrm{O} 3$ transports on tropospheric $\mathrm{O}_{3}$ levels, Tellus B, 49, 38-55, 1997.

Roelofs, G. J., Scheeren, H. A., Heland, J., Ziereis, H., and Lelieveld, J.: A model study of ozone in the eastern Mediterranean free troposphere during MINOS (August 2001), Atmos. Chem. Phys., 3, 1199-1210, doi:10.5194/acp-3-1199-2003, 2003.

Sander, R., Baumgaertner, A., Gromov, S., Harder, H., Jöckel, P., Kerkweg, A., Kubistin, D., Regelin, E., Riede, H., Sandu, A., Taraborrelli, D., Tost, H., and Xie, Z.-Q.: The atmospheric chemistry box model CAABA/MECCA-3.0, Geosci. Model Dev., 4, 373-380, doi:10.5194/gmd-4-373-2011, 2011.

Scheeren, H. A., Lelieveld, J., Roelofs, G. J., Williams, J., Fischer, H., de Reus, M., de Gouw, J. A., Warneke, C., Holzinger, R., Schlager, H., Klüpfel, T., Bolder, M., van der Veen, C., and Lawrence, M.: The impact of monsoon outflow from India and Southeast Asia in the upper troposphere over the eastern Mediterranean, Atmos. Chem. Phys., 3, 1589-1608, doi:10.5194/acp-31589-2003, 2003.

Sprenger, M. and Wernli, H.: A northern hemispheric climatology of cross-tropopause exchange for the ERA15 time period (19791993), J. Geophys. Res., 108, 8521, doi:10.1029/2002JD002636, 2003.

Sprenger, M., Wernli, H., and Bourqui, M.: StratosphereTroposphere Exchange and Its Relation to Potential Vorticity Streamers and Cutoffs near the Extratropical Tropopause, J. Atmos. Sci., 64, 1587-1602, doi:10.1175/JAS3911.1, 2007.

Stohl, A., James, P., Forster, C., Spichtinger N., Marenco, A., Thouret, V., and Smit, H. G. J.: An extension of MOZAIC ozone climatologies using trajectory statistics, J. Geophys. Res., 106, 27757-27768, 2001.
Tost, H., Jöckel, P., Kerkweg, A., Sander, R., and Lelieveld, J.: Technical note: A new comprehensive SCAVenging submodel for global atmospheric chemistry modelling, Atmos. Chem. Phys., 6, 565-574, doi:10.5194/acp-6-565-2006, 2006.

Traub, M. and Lelieveld, J.: Cross-tropopause transport over the eastern Mediterranean, J. Geophys. Res., 108, 4712, doi:10.1029/2003JD003754, 2003.

Tyrlis, E. and Lelieveld, J.: Climatology and dynamics of the summer Etesian winds over the Eastern Mediterranean, J. Atmos. Sci., 70, 3374-3396, doi:10.1175/JAS-D-13-035.1, 2013.

Tyrlis, E., Lelieveld, J., and Steil, B.: The summer circulation in the eastern Mediterranean and the Middle East: influence of the South Asian Monsoon, Clim. Dynam., 40, 1103-1123, doi:10.1007/s00382-012-1528-4, 2013a.

Tyrlis, E., Skerlak, B., Sprenger, M., Wernli, H., Zittis, G., and Lelieveld, J.: Dynamics and climatology of summertime tropopause fold activity over the eastern Mediterranean and the Middle East, J. Geophys. Res., submitted, 2013b.

Voulgarakis, A., Telford, P. J., Aghedo, A. M., Braesicke, P., Faluvegi, G., Abraham, N. L., Bowman, K. W., Pyle, J. A., and Shindell, D. T.: Global multi-year $\mathrm{O}_{3}-\mathrm{CO}$ correlation patterns from models and TES satellite observations, Atmos. Chem. Phys., 11, 5819-5838, doi:10.5194/acp-11-5819-2011, 2011.

Zanis, P., Trickl, T., Stohl, A., Wernli, H., Cooper, O., Zerefos, C., Gaeggeler, H., Schnabel, C., Tobler, L., Kubik, P. W., Priller, A., Scheel, H. E., Kanter, H. J., Cristofanelli, P., Forster, C., James, P., Gerasopoulos, E., Delcloo, A., Papayannis, A., and Claude, H.: Forecast, observation and modelling of a deep stratospheric intrusion event over Europe, Atmos. Chem. Phys., 3, 763-777, doi:10.5194/acp-3-763-2003, 2003.

Zerefos, C. S., Kourtidis, K. A., Melas, D., Balis, D., Zanis, P., Katsaros, L., Mantis, H. T., Repapis, C., Isaksen, I., Sundet, J., Herman, J., Bhartia, P. K., and Calpini, B.: Photochemical Activity and Solar Ultraviolet Radiation (PAUR) Modulation factors: An overview of the project, J. Geophys. Res., 107, 8134, doi:10.1029/2000JD000134, 2002.

Ziv, B., Saaroni, H., and Alpert, P.: The factors governing the summer regime of the Eastern Mediterranean, Int. J. Climatol., 24, 1859-1871, 2004. 